\title{
Application of Response Surface Methodology to Optimize Alkali Concentration, Corn Stover Particle Size, and Extruder Parameters for Maximum Sugar Recovery
}

\author{
Chinnadurai Karunanithy and Kasiviswanathan Muthukumarappan \\ Agricultural and Biosystems Engineering, South Dakota State University \\ South Dakota \\ USA
}

\section{Introduction}

The National Research Council (2000) has set a goal for the biobased industry of providing at least $10 \%$ of liquid fuels by the year 2020 and providing $50 \%$ of liquid fuels by the year 2050 . The 2007 Energy Act mandates the production of 21 billion gallons of biofuels from non-corn starch materials by 2022. Brazil and the US produce about $60 \%$ of the world's ethanol, exploiting sugarcane and corn, respectively. Economics and limitation in grain supply lead to search for alternative resources. Lignocellulosic materials are the most abundant renewable resources on earth (Lynd et al., 2005) and cheaper than corn. Among the crop residues, corn and wheat are the most abundant in the US, roughly $96 \%$ of the total biomass (Little, 2001). Corn stover is being considered as one of the main renewable feedstocks for conversion into fuels and chemicals. According to Kadam and McMillon (2003), about 80-100 dry tons of corn stover/year can be utilized for ethanol production. It has been estimated that approximately 256 million dry tons of corn stover will be available in the year 2030 due to collection technologies improvement and a steady yield increase (Perlack et al., 2005). Moreover, corn stover is projected as the feedstock in two of the six commercial-scale lignocellulosic biorefineries supported by the US Department of Energy (Service, 2007).

Ethanol production from biomass is quite different from the process used for corn grain, because the carbohydrates in biomass are more difficult for hydrolytic enzymes to access than the starch in grain (Gibbons et al., 1986). Unlike corn grain, biomass is composed of 40$50 \%$ cellulose, $25-35 \%$ hemicellulose, and 15-20\% lignin (Saha \& Bothast, 1997). Because of the complex structure of biomass and its recalcitrant nature, an additional step called pretreatment is required for ethanol production from biomass in addition to the steps involved in corn ethanol production. The purposes of pretreatment are to open up the biomass structure, to increase accessible surface area, to reduce the cellulose crystallinity, and to increase the porosity, pore size, and pore volume. Extensive pretreatment effort has been made using several methods on different biomasses with varying degrees of success. Acid, alkali, hydrothermal (steam, steam explosion, hot water, $\mathrm{pH}$ controlled hot water), and ammonia fiber expansion (AFEX) are a few well recognized pretreatment methods. 
Despite biomass pretreatment research of more than three decades, no perfect conversion technology has been established for biofuels production from biomass on a commercial scale (de Leon \& Coors, 2008).

Extrusion is a well known technology in the processed food, feed, and plastic industries. An extruder has the ability to provide high shear, rapid heat transfer, effective and rapid mixing in a short residence time, as well as adaptability to many different processes - all in a continuous process. A few extrusion pretreatments (Dale et al., 1999; de Virje et al., 2002; Karunanithy et al., 2008; Karunanithy \& Muthukumarappan, 2010a, 2010b, 2010c, 2011a, 2011b, 2011c; Lee et al., 2009; Muthukumarappan \& Julson, 2007 ) showed a significant improvement on sugar recovery from corn stover, switchgrass, miscanthus, prairie cord grass, big bluestem, and Douglas fir through enzymatic hydrolysis. Potential fermentation inhibitors such as furfural and HMF were not reported in any of the above studies. Karunanithy and Muthukumarappan (2011a) achieved 85.7, 87.5, and 86.3\% of glucose, xylose, and combined sugar recovery, respectively for the optimized pretreatment condition of $180^{\circ} \mathrm{C}$ barrel temperature, $155 \mathrm{rpm}$ screw speed, $20 \% \mathrm{wb}$ moisture content, and corn stover particle size $8 \mathrm{~mm}$. The literatures report a sugar recovery of more than $90 \%$ or near quantitative using dilute acid (Lloyd \& Wyman, 2005; Yan et al., 2009; Zhu et al., 2004, 2005), lime (Kim \& Holtzapple, 2005 ), compressed hot water (Liu \& Wyman, 2005), steam pretreatment (Bura et al., 2009), steam explosion (Elander et al., 2009; Tucker et al., 2003), a combination of acid and alkali (Varga et al., 2002), ammonia recycle process (Kim et al., 2003) and AFEX (Chundawat et al., 2007). These results show that there still is room to improve sugar recovery from corn stover when pretreated in extrusion in combination with other pretreatment methods.

In general, alkali pretreatment results in less degradation of the sugar compared to acid pretreatments. Considering the construction material of the extruder, addition of acid would lead to corrosion problem; therefore, extruder screws and barrel should be fabricated using acid-resistant stainless steel alloy such as AL6XN (Miller \& Hester, 2007). Alkali pretreatment can be as simple as soaking the biomass in $\mathrm{NaOH}$ at room temperature or as complicated as treating the biomass in AFEX. Among sodium, calcium, potassium, and ammonium hydroxides, sodium hydroxide is the most studied alkali in biomass pretreatment (Elshafei et al., 1991; MacDonald et al., 1983) and effective also (Keshwani, 2009). MacDonald et al (1983) obtained an overall yield of $77.5 \%$ from dilute $\mathrm{NaOH}$ pretreatment at a high temperature, whereas Elshafei et al (1991) achieved a theoretical maximum yield of cellulose when corn stover was soaked in $1.0 \mathrm{M} \mathrm{NaOH}$ for $24 \mathrm{~h}$ at room temperature. Recently, Gupta (2008) reported about $94 \%$ glucose digestibility when corn stover was pretreated with $1.5 \% \mathrm{NaOH}$ at $60^{\circ} \mathrm{C}$ for $24 \mathrm{~h}$.

Barrel temperature and screw speed are important extruder parameters, which can affect sugar recovery. Biomass size reduction has become an integral part of biomass pretreatment. Studies have shown that the particle size influences the diffusion kinetics (Kim \& Lee, 2002), the effectiveness of pretreatment (Chundawat et al., 2007), the enzymatic hydrolysis rate, the rheological properties (Chundawat et al., 2007; Desari \& Bersin, 2007), lignin removal (Hu et al., 2008), the sugar yield (Chang et al., 2001; Hu et al., 2008; Yang et al., 2008), acetic acid formation (Guo et al., 2008), and the power requirement for size reduction (Cadoche \& Lopez, 1989; Mani et al., 2004; van Walsum et al., 1996). It is a well known that alkali acts as delignification agent at low concentration without degrading the carbohydrates. Hence, the extruder barrel temperature, screw speed, corn stover particle size, and alkali $(\mathrm{NaOH})$ concentration are the independent variables selected for this study. 
Optimization of pretreatment conditions is one of the most important stages in the development of an efficient and economic pretreatment method. The traditional one-factor-ata-time approach is time consuming; moreover, the interactions between independent variables are not considered. Response surface methodology (RSM) is an effective optimization tool wherein many factors and their interactions affecting the response can be identified with fewer experimental trials than one-factor-at-a-time experiment. RSM has been widely used in various fields ranging from food process operations including extrusion (Altan et al., 2008; Jorge et al., 2006), food product development, media composition in biotechnology to bioprocessing such as enzymatic hydrolysis and fermentation. Recently, RSM has been successfully applied to biomass pretreatment by many researchers (Canettieri et al., 2007; Kim \& Mazza, 2008; Lu et al., 2007; Neureiter et al., 2002; Rahman et al., 2007; Xin \& Saka, 2008). Earlier extrusion pretreatment studies conducted by the authors yielded encouraging results and however, the extrusion factors including alkali concentration were not optimized. The following are the objectives of the present study: 1) to understand and optimize the effect of extruder parameters such as barrel temperature and screw speed, biomass particle size, and alkali $(\mathrm{NaOH})$ concentration for maximum sugar recovery using RSM and adopting a central composite rotatable design (CCRD), and 2) to propose a mathematical model to predict glucose, xylose, and combined sugar recovery from corn stover.

\section{Materials and methods}

\subsection{Experimental design}

A central composite rotatable design (CCRD) with four independent variables was used to study the response pattern and to determine the optimum combination of temperature, screw speed, alkali concentration, and particle size for maximizing the sugar recovery from corn stover. The CCRD combines the vertices of the hypercube whose coordinates are given by a $2^{n}$ factorial design with star points. The star points provide the estimation of curvature of the nonlinear response surface. The experimental design was developed using Design Expert 7.1.6 (2002), which resulted in 30 runs, in addition 6 more center points were added to allow for the estimation of the pure error sum squares. The 36 experiments ( 16 factorial, 8 star, and 12 center points) were randomized to maximize the effects of unexplained variability in the observed responses due to extraneous factors. Independent variable levels were selected based on a previous and one-factor-at-a-time experiment. The independent variables were coded according to the following equation

$$
x_{i}=\left(X_{i}-X_{0}\right) / \Delta X_{i}
$$

where $x_{i}$ and $X_{i}$ are the dimensionless and actual values of the independent variable $i, X_{0}$ is the actual value of the independent variable at the center point, and $\Delta X_{i}$ is the step change of $X_{i}$ corresponding to a unit variation of the dimensionless value. The variables optimized included barrel temperature $\left(45\right.$ to $\left.225^{\circ} \mathrm{C}\right)$, screw speed (20 to $\left.200 \mathrm{rpm}\right)$, alkali concentration ( 0.5 to $2.5 \%$ ), and particle size ( 2 to $10 \mathrm{~mm}$ ) each at five levels: $-2,-1,0,1$, and 2 and shown in Table 2.

\subsection{Biomass preparation}

Corn stover obtained from a local farm was ground in a hammer mill (Speedy King, Winona Attrition Mill Co, MN) using 2, 4, 6, 8, and $10 \mathrm{~mm}$ sieves to understand the influence of 
particle size on sugar recovery. Compositional analysis of corn stover such as glucose, xylose, mannose, arabinose, lignin, and ash was done following Sluiter et al (2008a, 2008b) and reported in the mass balance diagram.

Alkali $(\mathrm{NaOH})$ solutions of different concentrations $(0.5,1.0,1.5,2.0$, and $2.5 \% \mathrm{w} / \mathrm{v})$ were prepared. It was found that corn stover required nine times of solution than that of corn stover weight for complete soaking, which is equivalent to $10 \%$ solids loading rate. The different particle size of corn stover was soaked in different alkali concentrations as given in the experimental design for $30 \mathrm{~min}$ at room temperature. The black liquid was drained out using cheese cloth followed by manual squeezing to remove excess moisture. Moisture content of the biomass samples was determined as described by Sluiter et al (2008c). The moisture content of alkali soaked samples was in the range of $75-78 \% \mathrm{wb}$.

\subsection{Extrusion pretreatment}

Extrusion was performed using a single screw extruder (Brabender Plasti-corder Extruder Model PL 2000, Hackensack, NJ), which had a barrel length to screw diameter ratio (l/d) of 20:1. In order to have a smooth biomass (plug) flow into the die section, the screw discharge end was fitted with conical metal piece. A screw with 3:1compression ratio was selected based on a previous study (Karunanithy \& Muthukumarappan, 2010a). The single screw extruder was fitted to a $7.5 \mathrm{hp}$ motor, which had a provision to adjust the screw speed from 0 to $210 \mathrm{rpm}$. The extruder barrel had provisions to control the temperature of the feed and transition zone in both barrel and die section. The extruder barrel temperature and the screw speed were controlled by a computer connected to the extruder. Extruder feeding was done manually. Compressed air was supplied as a cooling agent along the barrel length. Once the barrel temperature stabilized, about $500 \mathrm{~g}$ of biomass was extruded under each pretreatment condition, divided into two batches accounting for variations due to extruder operation, and considered replicates. The mean residence time varied between 30 and $90 \mathrm{sec}$ depending upon the screw speed.

\subsection{Enzymatic hydrolysis}

Enzymatic hydrolysis of pretreated samples $(0.3 \mathrm{~g}$ in $10 \mathrm{~mL}$ hydrolysis volume) was carried out using $0.1 \mathrm{M}, \mathrm{pH} 4.8$ sodium citrate buffer for $72 \mathrm{~h}$ at $50^{\circ} \mathrm{C}$ and $150 \mathrm{rpm}$ as described by Selig et al (2008). Based on the literature survey and earlier study, the amount of cellulase (Celluclast 1.5L, activity $70 \mathrm{FPU} / \mathrm{g}$ ) enzyme was decided to be $15 \mathrm{FPU} / \mathrm{g}$ of dry matter. The ratio of cellulase to $\beta$ - glucosidase (Novo-188, activity $250 \mathrm{CBU} / \mathrm{g}$ ) was maintained at 1:4 based on earlier study (Karunanithy \& Muthukumarappan, 2010b). All these enzymes were provided by Novozyme (Krogshoejvej, Denmark). After hydrolysis, the samples were kept in boiling water for $10 \mathrm{~min}$ to inactivate the enzyme action. The supernatant was centrifuged with $16060 \mathrm{~g}$ force (13000 rpm for $15 \mathrm{~min}$ ) and then frozen twice before injecting into the HPLC to remove the impurities which contribute to the pressure increase in the HPLC system. Soluble sugar was quantified using HPLC (Agilent Technologies, Santa Clara, CA; Bio-Rad Aminex 87H column, Hercules, CA) with a mobile phase of $0.005 \mathrm{M} \mathrm{H}_{2} \mathrm{SO}_{4}$ at a flow rate of $0.6 \mathrm{~mL} / \mathrm{min}$ at $65^{\circ} \mathrm{C}$ and a sample volume of $20 \mu \mathrm{L}$ as mentioned by Sluiter et al (2008d). The sugar concentration obtained from chromatogram was divided by dry weight of biomass taken for enzymatic hydrolysis in order to know the percentage of different sugars with respect to total biomass. Glucose and xylose are the major sugars present in the biomass as compared to arabinose. Instead of reporting arabinose separately, it was added 
with glucose and xylose and reported as combined sugar. The sugar recovery reported in this chapter was after enzymatic hydrolysis of the pretreated samples.

$$
\begin{gathered}
Y_{i}, \%=\frac{S_{i p}}{S_{i r}} * 100 \\
Y_{c}, \%=\frac{\sum S_{i p}}{\sum S_{i r}} * 100
\end{gathered}
$$

Where

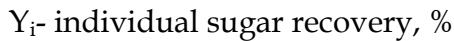

$\mathrm{Y}_{\mathrm{c}}$ - combined sugar recovery, $\%$

$\mathrm{S}_{\mathrm{ip}}$ - individual sugar obtained from hydrolyzate of pretreated samples through HPLC

$S_{\text {ir }}$ - individual sugar from raw material

\subsection{Statistical analysis}

The second order polynomial equation was used to describe the effect of independent variables in terms of linear, quadratic, and interactions. The proposed model for the response $\left(\mathrm{Y}_{\mathrm{i}}\right)$ was:

$$
Y_{i}=b_{0}+\sum_{i=1}^{4} b_{i} X_{i}+\sum_{i=1}^{4} b_{i i} X_{i}^{2}+\sum_{i=1}^{3} \sum_{j=i+1}^{4} b_{i j} X_{i} X_{j}+\varepsilon
$$

where $Y_{i}$ is the predicted response; $b_{0}$ is the interception coefficient; $b_{i}, b_{i i}$, and $b_{i j}$ are linear, quadratic, and interaction terms; $\varepsilon$ is the random error, and $X_{i}$ is the independent variables studied. Design Expert 7.1.6 software was used for regression and graphical analysis of the data obtained. Statistical analysis of the model was performed to evaluate the analysis of variance.

The quality of fit of second order equation was expressed by the coefficient of determination $\mathrm{R}^{2}$ and its statistical significance $(\alpha=0.05)$ was determined by the $\mathrm{F}$ test. The individual effect of each variable and also the effects of the interaction were determined. Optimization (maximizing sugar recovery) of the fitted polynomial was determined using numerical optimization contained in the Design Expert 7.1.6. After optimizing the pretreatment conditions using RSM, validation was done by extruding corn stover at two different optimum conditions of barrel temperature, screw speed, alkali concentration, and particle size from the numerical solution, depending on the particle size, due to availability of the standard sieve size.

\section{Results and discussion}

\subsection{Solid loss and washing of the pretreated corn stover}

Many researchers (Dawson \& Boopathy, 2007; Kaar \& Holtzapple, 2000; Titgemeyer et al., 1996) have reported washing of the biomass with different medium after alkali pretreatment; however, it may not be necessary if the alkali concentration is low enough. According to Novozymes biomass kit, most of the enzymes have optimum activity between a $\mathrm{pH}$ of 4.5 to 6.5 at $45-70^{\circ} \mathrm{C}$. When different biomasses soaked with different alkali concentration, the sample prepared for enzymatic hydrolysis (after adding citrate buffer, DI 
water, and enzymes) had a $\mathrm{pH}$ of 4.8 to 5.4 , which is well within the range of Novozyme's recommendations. Depending upon the alkali concentration and particle size, a sugar recovery of $35-45 \%$ was recorded. However, the washed samples had lower sugar recovery (due to loss of sugar about 5-7\%) than that of unwashed samples.

Considering the solid loss (15\%) and delignification (40\%) during alkali soaking, the sugar recovery was calculated and shown in the mass balance diagram. The literature values of solid loss and delignification varied from 10.0-67.3 and 27.7-96.0\%, respectively, depending upon the alkali usage and the pretreatment conditions employed on corn stover as listed in Table 1. The reason for lower solid loss and delignification is due to room temperature when compared to most of methods mentioned in the table.

\subsection{Effect of independent variables on sugar recoveries}

The experimental glucose, xylose, and combined sugar recoveries from different treatment combinations are presented in Table 2. The proposed quadratic models in terms of actual variables are given below for glucose $\left(Y_{G}\right)$, xylose $\left(Y_{X}\right)$, and combined sugar $\left(Y_{C}\right)$ recovery, where $X_{1}, X_{2}, X_{3}$, and $X_{4}$ represent barrel temperature $\left({ }^{\circ} \mathrm{C}\right)$, screw speed (rpm), alkali concentration $(\% \mathrm{w} / \mathrm{v})$, and particle size $(\mathrm{mm})$ of corn stover, respectively. Similar equations were reported for acid hydrolysis of sugarcane bagasse (Neureiter et al., 2002), oil palm empty fruit bunch (Rahman et al., 2007), eucalyptus (Canettieri et al., 2007), for concentrated acid pretreatment of pine wood (Miller \& Hester, 2007 ), acid catalyzed fractionation and enzymatic hydrolysis of flax shives (Kim \& Mazza, 2008), hot-compressed water pretreatment of Japanese beech hydrolysis (Xin \& Saka, 2008), and extrusion pretreatment of corn stover (Karunanithy \& Muthukumarappan, 2011a). Those equations predict the responses well with high $\mathrm{R}^{2}$ and low probability values.

$$
\begin{aligned}
& Y_{G}=-206.7+0.9664 X_{1}+0.4352 X_{2}+192.8 X_{3}+17.76 X_{4}+0.0024 X_{1} X_{2}-0.0172 X_{1} X_{3} \\
&+0.0178 X_{1} X_{4}-0.3881 X_{2} X_{3}-0.0190 X_{2} X_{4}+3.8485 X_{3} X_{4}-0.0045 X_{1}^{2}-0.0009 X_{2}^{2} \\
&-50.503 X_{3}^{2}-1.7979 X_{4}^{2} \\
& Y_{X}=-141.13+0.6135 X_{1}+0.4986 X_{2}+168.87 X_{3}+8.895 X_{4}+0.0014 X_{1} X_{2}-0.0803 X_{1} X_{3} \\
&+ 0.0245 X_{1} X_{4}-0.1693 X_{2} X_{3}+1.6732 X_{3} X_{4}-0.0029 X_{1}^{2}-0.0021 X_{2}^{2}-46.837 X_{3}^{2}-1.094 X_{4}^{2} \\
& Y_{C}=-190.54+0.8375 X_{1}+0.5593 X_{2}+186.72 X_{3}+15.47 X_{4}+0.0021 X_{1} X_{2}-0.0962 X_{1} X_{3} \\
&+ 0.0228 X_{1} X_{4}-0.3206 X_{2} X_{3}-0.0239 X_{2} X_{4}+3.041 X_{3} X_{4}-0.0039 X_{1}^{2}-0.0015 X_{2}^{2} \\
&-48.92 X_{3}^{2}-1.5658 X_{4}^{2}
\end{aligned}
$$

The regression coefficient, standard error, $\mathrm{F}$, and $\mathrm{p}$ values are shown in Table 3 . All the independent variables had a significant influence on sugar recoveries, as evident from their $\mathrm{p}$ values in Table 3. All the independent variables had a positive influence on all the sugar recoveries, as evident from the proposed model equations. The magnitude of the terms indicates the order of influence on sugar recoveries i.e., alkali concentration, particle size, barrel temperature, and screw speed. Not only the linear terms of independent variables but also their quadratic terms contributed to glucose, xylose, and combined sugar recovery, as evident from equation 5 and 7. Again, the difference in magnitude of the quadratic terms explains which variable was dominant for sugar recoveries. 


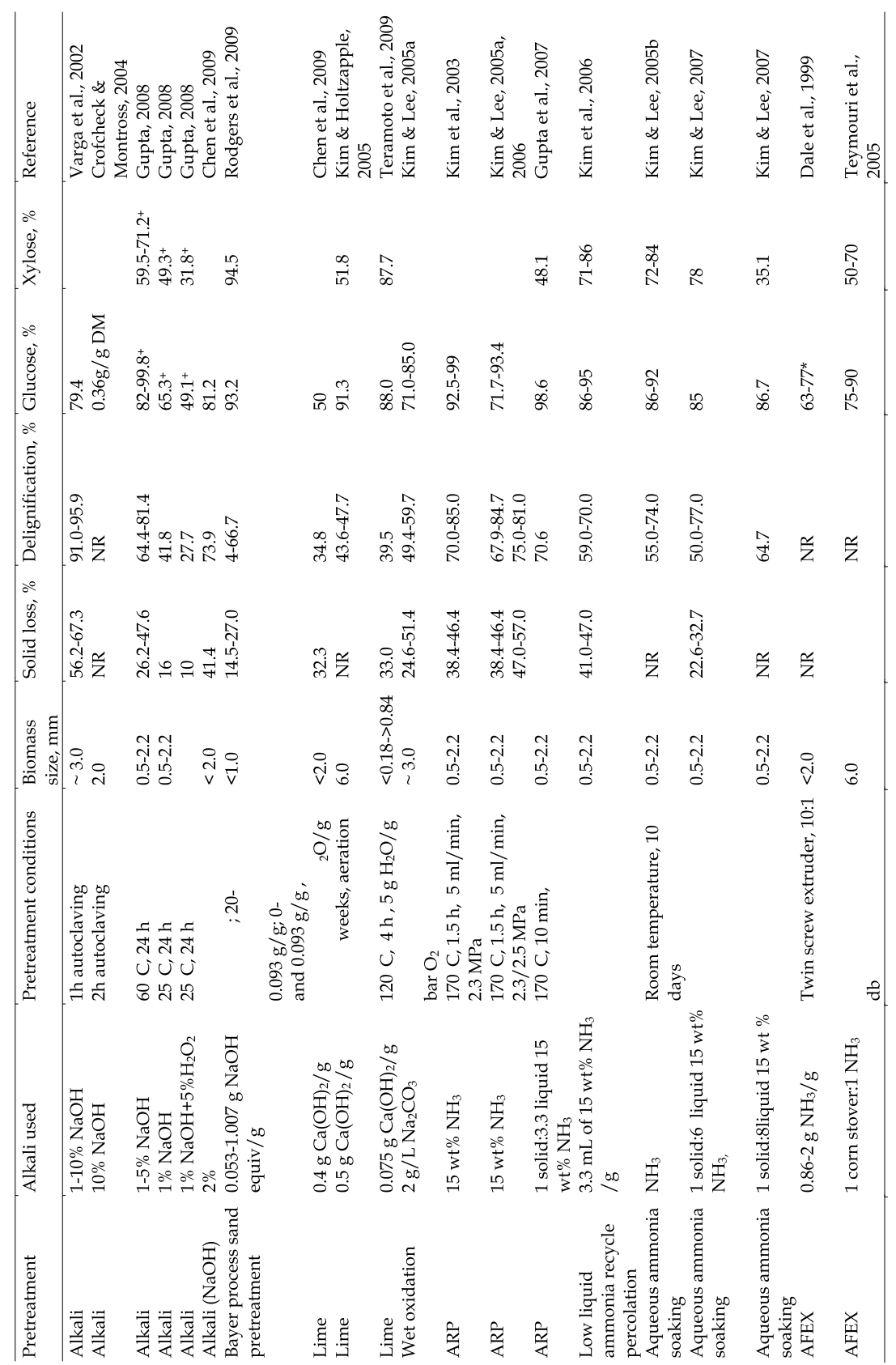

* ruminant digestibility + enzymatic digestibility

Table 1. Different alkali pretreatment methods employed on corn stover and their results as reported in literature 


\begin{tabular}{|c|c|c|c|c|c|c|c|c|c|c|c|c|c|}
\hline \multirow[b]{2}{*}{ Treat } & \multirow[b]{2}{*}{ Temp } & \multirow[b]{2}{*}{ Speed } & \multirow[b]{2}{*}{ Alkali } & \multicolumn{4}{|c|}{ Glucose, \% } & \multicolumn{3}{|c|}{ Xylose, \% } & \multicolumn{3}{|c|}{ Combined sugar, $\%$} \\
\hline & & & & PS & Obsd & Pred & Resl & Obsd & Pred & Resl & Obsd & Pred & Resl \\
\hline 1 & $0(135)$ & $0(110)$ & $0(1.5)$ & $0(6)$ & 91.3 & 89.0 & 2.3 & 86.5 & 87.0 & -0.5 & 92.0 & 89.2 & 2.8 \\
\hline 2 & $1(180)$ & $-1(65)$ & $1(2.0)$ & $-1(4)$ & 61.6 & 61.7 & -0.1 & 64.4 & 63.1 & 1.3 & 60.4 & 9.8 & 0.6 \\
\hline 3 & $0(135)$ & $0(110)$ & $0(1.5)$ & $0(6)$ & 86.3 & & -2.7 & 84.1 & 87.0 & -2.9 & & 89.2 & -0.3 \\
\hline 4 & $1(180)$ & $-1(65)$ & $1(2.0)$ & $1(8)$ & 87.0 & 85.1 & 1.9 & 75.0 & 74.8 & 0.2 & 83.0 & .1 & 1.9 \\
\hline 5 & $0(13$ & $0(1$ & & $0(6$ & 90.0 & & 1.0 & 87.2 & 87.0 & 0.2 & & .2 & -1.3 \\
\hline 6 & $0(135)$ & $0(110)$ & $0(1$. & $0(6$ & 87.8 & & -1.2 & 85.1 & 87.0 & -1.9 & & .2 & -1.8 \\
\hline 7 & $1(180)$ & $1(155)$ & $1(2.0)$ & $-1(4)$ & 43.7 & 3 & -0.6 & 56.8 & 56.3 & 0.5 & 48.1 & 7.9 & 0.2 \\
\hline 8 & $-1(90)$ & $-1(65)$ & (1.0) & $-1(4)$ & 52.8 & & 0.9 & 57.8 & 57.9 & -0.1 & 55.3 & 54.5 & 0.8 \\
\hline 9 & $0(135)$ & $0(110)$ & $0(1.5)$ & $0(6)$ & .1 & & -0.9 & 90.0 & .0 & 3.0 & & & 1.1 \\
\hline 10 & $-1(90)$ & $1(155)$ & $-1(1.0)$ & $-1(4)$ & 48.9 & 50.0 & -1.1 & 57.0 & 54.8 & 2.2 & & 3 & 0 \\
\hline 11 & $0(135)$ & $0(110)$ & $0(1.5$ & $2(10$ & 68.3 & & -1.0 & 70.5 & 71.7 & -1.2 & & 71.0 & -1.3 \\
\hline 12 & $0(135)$ & $2(200)$ & $0(1$ & $0(6)$ & 67.9 & 2 & -0.3 & 62.5 & 63.7 & -1.2 & & 6 & -0.8 \\
\hline 13 & $1(180)$ & $1(155)$ & $-1(1.0)$ & $1(8)$ & 61.8 & 6 & 0.1 & 66.0 & 63.6 & 2.4 & 65.4 & 63.3 & 2.1 \\
\hline 14 & $-1(90)$ & $-1(65)$ & $1(2.0)$ & $-1(4)$ & 77.7 & & 0.7 & 74.8 & .7 & 0.1 & .9 & .1 & -0.2 \\
\hline 15 & $0(135)$ & $0(110)$ & $0(1$ & $0(6$ & 88.0 & & -1.0 & 90.1 & 87.0 & 3.1 & & 89.2 & 0.1 \\
\hline 16 & $0(135)$ & $0(110)$ & $2(2$ & $0(6$ & 49.2 & 50.7 & -1.5 & 47.0 & 49.1 & -2.1 & 48.3 & 50.3 & -2.0 \\
\hline 17 & $0(135)$ & $0(110)$ & $0(1$ & $0(6$ & 89.2 & & 0 & 85.9 & 87.0 & -1.1 & & .2 & 0.2 \\
\hline 18 & $0(135)$ & $0(110)$ & $0(1$ & $0(6$ & 87.8 & 89.0 & -1.2 & 85.5 & 87.0 & -1.5 & 86.9 & 89.2 & -2.3 \\
\hline 19 & $-2(45)$ & $0(110)$ & $0(1.5)$ & $0(6)$ & 49.6 & 51.6 & -2.0 & 59.1 & 61.6 & -2.5 & 55.6 & 57.6 & -2.0 \\
\hline 20 & $0(135)$ & $0(11$ & & 0( & 90.8 & & & 87.8 & & 0.8 & & ) & 1.9 \\
\hline 21 & $-1(90)$ & $1(155)$ & $1(1.0)$ & $1(8$ & 46.6 & 44.7 & 1.9 & 47.1 & 47.6 & -0.5 & 47.1 & 46.6 & 0.5 \\
\hline 22 & $1(180)$ & $-1(65)$ & $-1(1.0)$ & $1(8)$ & 49.8 & & -1.2 & 57.0 & .5 & -1.5 & .1 & 5.0 & -1.9 \\
\hline 23 & $-1(90)$ & $-1(6$ & & 1( & 95.4 & & & 80.1 & & 2.6 & & 90.2 & 1.9 \\
\hline 24 & $0(135)$ & $-2(20)$ & $0(1.5)$ & $0(6)$ & 92.2 & 94.4 & -2.2 & 74.7 & 76.9 & -2.2 & 85.0 & 87.2 & -2.2 \\
\hline 25 & $0(135)$ & $0(11$ & & 0( & 89.7 & & 0 & 87.0 & 87.0 & 0 & 3 & 89.2 & 0.1 \\
\hline 26 & $0(135)$ & $0(110)$ & $0(1$. & $0(6$ & 89.7 & 89.0 & 0.7 & 86.6 & 87.0 & -0.4 & 88.2 & 89.2 & -1.0 \\
\hline 27 & $1(180)$ & $-1(65)$ & $-1(1.0)$ & $-1(4)$ & 45.3 & 43.0 & 2.3 & 56.3 & 53.5 & 2.8 & 48.4 & 45.8 & 2.6 \\
\hline 28 & $0(135)$ & $0(110)$ & $-2(0.5)$ & $0(6$ & 25.2 & & -1 & 30.1 & 31.2 & -1.1 & 29.4 & 30.4 & -1.0 \\
\hline 29 & $0(135)$ & $0(110)$ & $0(1.5)$ & $-2(2)$ & 49.7 & 51.2 & -1.5 & 65.2 & 67.3 & -2.1 & 55.7 & 57.4 & -1.7 \\
\hline 30 & $-1(90)$ & 1(155) & $1(2.0)$ & $-1(4$ & 43.2 & 40.2 & 3. & 58.7 & 56.4 & 2.3 & 51.0 & 48.1 & 2.9 \\
\hline 31 & $-1(90)$ & $-1(65)$ & $-1(1.0)$ & 1(8) & 54.8 & 53.5 & 1.3 & 56.1 & 54.0 & 2.1 & 57.0 & 55.4 & 1.7 \\
\hline 32 & $1(180)$ & $1(155)$ & $-1(1.0)$ & $-1(4)$ & 61.0 & 60.5 & 0.5 & 60.2 & 62.0 & -1.8 & 62.0 & 62.8 & -0.8 \\
\hline 33 & $-1(90)$ & & $1(2$. & $1(\xi$ & 48.8 & 50.3 & -1.5 & 55.5 & 55.9 & -0.4 & 51.9 & 52.6 & -0.7 \\
\hline 34 & $2(225)$ & $0(110)$ & $0(1.5)$ & $0(6)$ & 52.6 & 53.2 & -0.6 & 65.3 & 66.1 & -0.8 & 56.0 & 57.0 & -1.0 \\
\hline 35 & $0(135)$ & $0(110)$ & $0(1.5)$ & $0(6$ & 89.4 & 89.0 & 0. & 88.3 & 87.0 & 1.3 & 90.3 & 89.2 & 1.1 \\
\hline 36 & $1(180)$ & $1(155)$ & $1(2.0)$ & $1(8)$ & 61.7 & 60.9 & 0.8 & 65.5 & 64.7 & 0.8 & 60.8 & 60.6 & 0.2 \\
\hline
\end{tabular}

Table 2. Experimental design showing both coded and actual values of variables, observed and predicted responses 


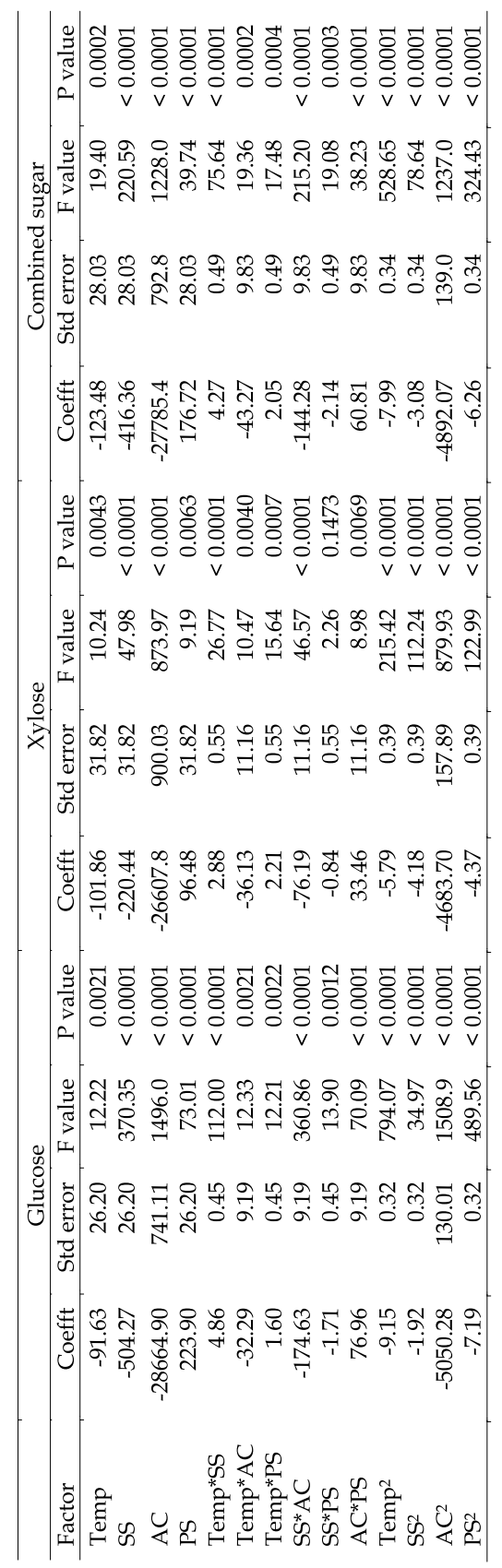

SS- screw speed AC-alkali concentration PS - particle size

Table 3. Coefficient values of the fitted model for different responses 
As mentioned earlier, alkali soaked samples had moisture content in the range of $75-78 \%$ $(w b)$. Friction is the main mode of material conveyance in a single screw extruder (Yeh \& Jaw, 1998). Because water acts as lubricant in the extruder (Hayasi et al., 1992), an increase in moisture content resulted in decrease in the friction between the material, screw shaft, and barrel (Chen et al., 2009) resulted in less disturbance to cell wall of the corn stover. An increase in temperature and screw speed will introduce more energy to the material in the barrel, which would enhance the moisture evaporation at the exit (Yu et al., 2009); thereby, the disturbance to cell wall structure of the corn stover was high. An increase in corn stover particle size increased the glucose, xylose, and combined sugar recovery. Similar trends have been reported for corn stover pretreated with lime (Chang et al., 2001), hot water (Zeng et al., 2007) and wheat straw pretreated in wet oxidation (Pedersen \& Meyer, 2009). It has been reported that sugar yield was more pronounced for larger particles $(0.42-1.00 \mathrm{~mm})$ than smaller particles $(0.05-0.15 \mathrm{~mm})$ due to topological changes of biomass in lime, hot water, and wet oxidation pretreatment (Chang et al., 2001; Pedersen \& Meyer, 2009; Teramoto et al., 2009). An increase of sugar yield with decrease in particle size was reported for corn stover pretreated in AFEX (Chundawat et al., 2007) and wheat straw irradiated with 500 kGy (Yang et al., 2008). Kaar and Holtzapple (2000) found that particle size $(<0.8-0.84$ $\mathrm{mm}$ ) had no effect on sugar yield from lime pretreatment of corn stover; more than $95 \%$ enzymatic hydrolysis yield was reported from SFEC pretreatment at $180 / 200^{\circ} \mathrm{C}$ irrespective of eucalyptus flour size ( $<2$ or $<5 \mathrm{~mm}$ ) by Teramoto et al (2009). Similarly Guo et al (2008) reported that feedstock size had no impact on the performance of dilute acid pretreatment at an input size below $1 \times 5 \mathrm{~cm}$.

Not only linear and quadratic terms but also interactions terms were contributed to sugar recoveries as evident from Table 3 and equations 5-7. In order to visualize the interaction effects for glucose recovery, significant interaction response surfaces are shown in Figure 1af. As noted in the figure, all the possible interactions had a significant effect on glucose recovery. An increase in screw speed showed a clear negative trend on glucose recovery at low temperature, whereas the glucose recovery was same across screw speeds, as evident from the interaction of temperature with screw speed (Fig. 1a). The glucose recovery of $92 \%$ can be achieved with the barrel temperature between $130-140^{\circ} \mathrm{C}$ along with $1.5-1.8 \%$ alkali concentration as seen from the interaction of the temperature and alkali concentration (Fig. $1 \mathrm{~b})$. The effect of temperature was prominent with a larger particle size $(8 \mathrm{~mm})$ than that of a smaller particle $(4 \mathrm{~mm})$, as seen from their interaction surface plot (Fig.1c). The glucose recovery increased with an increase in particle size regardless of barrel temperature as it was clear from their interaction. As noted from the dome shape surface plot that the maximum glucose recovery can be obtained at the barrel temperature between 130 to $140^{\circ} \mathrm{C}$. These results suggested that the temperature of $130-140^{\circ} \mathrm{C}$ would be sufficient to remove the moisture through vaporization; further increase in temperature may result in thermal softening of corn stover.

The alkali interaction with screw speed indicated that the alkali concentration of 1.5 to $1.7 \%$ would be good enough to obtain a glucose recovery of $95 \%$. An alkali concentration up to $1.7 \%$ increased glucose recovery, a further increase in concentration of alkali resulted in decrease on glucose recovery, as evident from the interaction of alkali concentration with screw speed (Fig. 1d). The screw speed had a minimum effect on glucose recovery at a $1 \%$ alkali concentration; however, the screw speed effect was reversed at a $2 \%$ alkali concentration. The increase in screw speed showed a negative influence on glucose recovery 


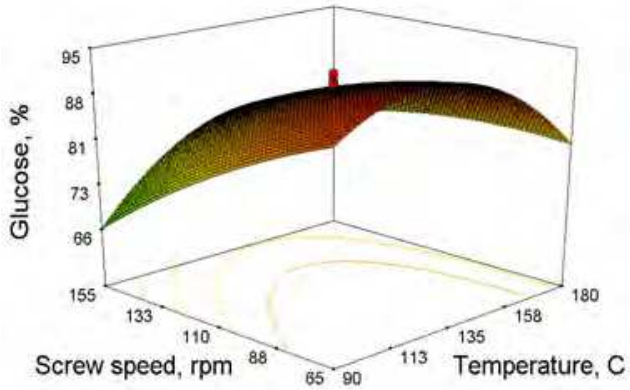

(a)

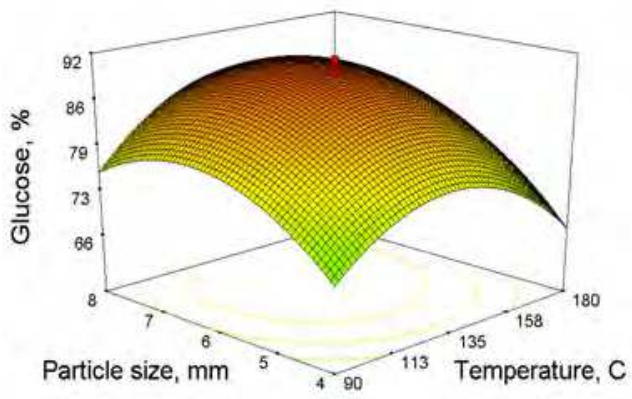

(c)

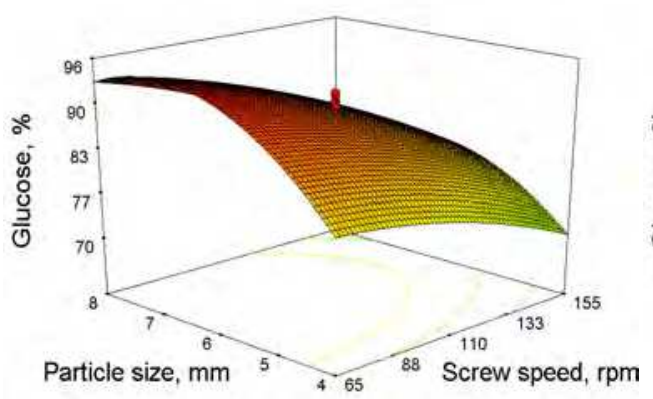

(e)

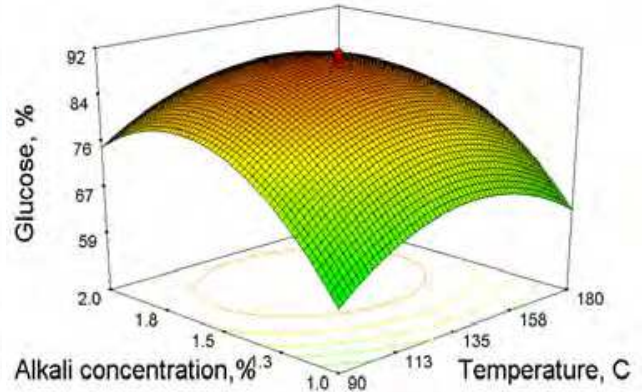

(b)

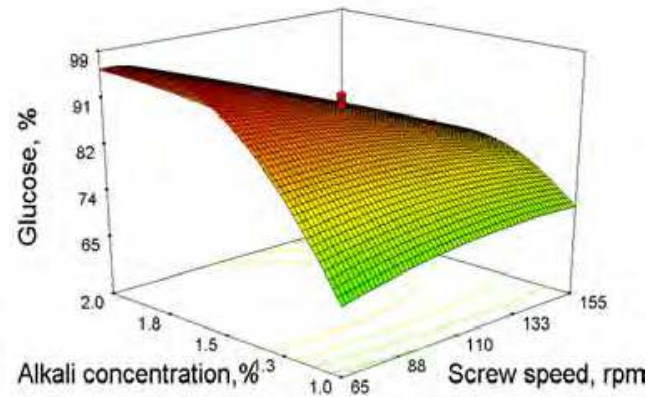

(d)

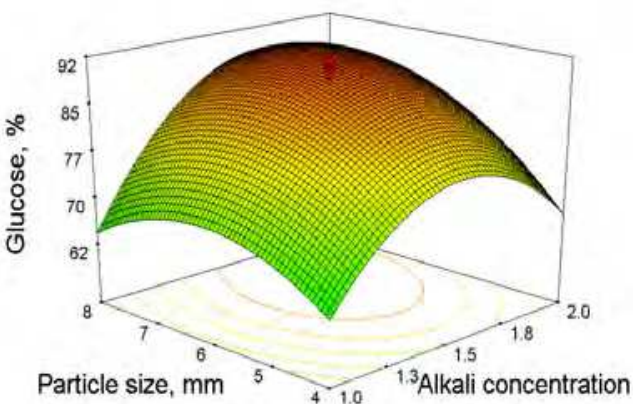

(f)

Fig. 1. Interaction effect of two independent variables on glucose recovery from corn stover (when other factors fixed at the center point: $135^{\circ} \mathrm{C}, 110, \mathrm{rpm}, 1.5 \% \mathrm{w} / \mathrm{w}$, and $6 \mathrm{~mm}$ ) 
regardless of the particle size as seen from their interaction (Fig. 1e). The particle size impact on glucose recovery was prominent at a lower screw $(65 \mathrm{rpm})$ speed than that of higher screw speed, as observed in Fig. 1e. The glucose recovery increased with an increase in particle size as evident from the interaction of particle size with temperature or screw speed; however, when particle size interacting with alkali concentration, the glucose recovery increase was noticed till $7 \mathrm{~mm}$ only (Fig. 1f). Again, the alkali concentration of $1.5-1.7 \%$ would give the maximum of $92 \%$ glucose recovery as seen from the alkali concentration interaction with particle size. These results showed that more than $90 \%$ glucose recovery was possible at a low screw speed, alkali concentration between 1.5 to $1.7 \%$ with particle size of 6-7 mm.

Xylose response surface obtained for the significant interactions of the independent variables through model prediction are shown in Fig. 2a-e. Except screw speed interaction with particle size, all other interactions had an impact on xylose recovery from corn stover. The maximum xylose recovery was predicted at a low screw speed $(65 \mathrm{rpm})$ and the barrel temperature between 130 and $140^{\circ} \mathrm{C}$, as evident from the dome shape surface plot (Fig. 2a). The screw speed showed a prominent effect on xylose recovery at a lower screw speed (65 $\mathrm{rpm})$ as compared to a higher screw speed (155 rpm) might be due to more residence time, as seen in Fig. 2a. As observed from the interaction of temperature with alkali concentration, an increase in alkali concentration and temperature had a positive influence on xylose recovery (Fig. 2b). However, the xylose recovery increase was significant till $1.7 \%$ alkali concentration and the barrel temperature between 130 and $140^{\circ} \mathrm{C}$. The interaction of temperature and particle size indicated that the increase in particle size up to $7 \mathrm{~mm}$ exhibited a direct relation with xylose recovery (Fig. 2c). Again, this interaction confirmed that the barrel temperature of $130-140^{\circ} \mathrm{C}$ would result in a xylose recovery of $91 \%$. Interaction of screw speed and alkali concentration for xylose recovery was similar to glucose recovery; alkali concentration had more prominent effect than that of screw speed. An increase in screw speed had a minimum effect on xylose recovery at an alkali concentration of $1 \%$; however, its effect was clear at a $2 \%$ alkali concentration (Fig. $2 \mathrm{~d}$ ). The xylose recovery increased with an increase in alkali concentration till $1.7 \%$ and then the increase was negligible as evident from the surface plot (Fig. 2e). The effect of particle size on xylose recovery was similar across the alkali concentrations. The xylose recovery of $91 \%$ was predicted with alkali concentration of $1.7 \%$ regardless of the particle size. The barrel temperature of $130-150^{\circ} \mathrm{C}$, low screw speed, 1.5 to $1.7 \%$ alkali concentration, and $6-7 \mathrm{~mm}$ corn stover particle size would result in a higher xylose recovery.

The predicted combined sugar response surfaces for the interactions among the independent variables are depicted in Fig. 3a-f. It can be noted that all the possible interactions had contributed for the combined sugar recovery. In general, the screw speed had a negative effect on combined sugar recovery, whereas the particle size had a positive effect, and this trend was also observed in glucose and xylose recovery. This trend might be attributed to a high mean residence time at a low screw speed and a greater resistance offered by a larger particle. The barrel temperature and alkali concentration were somewhere middle of the range results in a higher combined sugar recovery as similar to glucose and xylose recovery. Since the combined sugar is the addition of glucose, xylose, and arabinose, arabinose is being small amount and followed the same trend. The combined sugar recovery of more than $93 \%$ was possible depending upon the interaction of independent variables, which was similar to glucose and xylose recoveries. 


\subsection{Comparison of alkali soaking-extrusion results with other pretreatment methods}

The maximum glucose $(91.3 \%)$, xylose $(86.5 \%)$, and combined sugar $(92.0 \%)$ recovery was recorded for the treatment combination of $130^{\circ} \mathrm{C}, 110 \mathrm{rpm}, 1.5 \%$ alkali concentration, and a 6 $\mathrm{mm}$ particle size. These pretreatment conditions differed from the maximum sugar recovery conditions $\left(180^{\circ} \mathrm{C}, 155 \mathrm{rpm}, 20 \%\right.$ moisture content, and $\left.8 \mathrm{~mm}\right)$ reported by Karunanithy and Muthukumarappan (2011b). These authors reported a glucose, xylose, and combined sugar recovery of 88,90 , and $90 \%$, respectively, for optimum pretreated corn stover with only extrusion. The results were comparable to each other, indicating that extrusion alone is good enough to obtain about $90 \%$ sugar recovery. This might be due to loss of hemicellulose during alkali soaking; otherwise, the sugar recovery would have reached a near quantitative. Recently, in another study authors (2010a) have reported about $90 \%$ sugar recoveries for the pretreatment conditions $\left(150^{\circ} \mathrm{C}, 150 \mathrm{rpm}, 4 \mathrm{~mm}\right.$ corn stover particle size with a $15 \%$ moisture content using 3:1 screw compression ratio). This might be due to a difference in the pretreatment conditions employed and possibly sugar loss during alkali soaking.

The present results were higher than the literature values for different biomasses. de Vrije et al (2002) reported $77 \%$ delignification, $69 \%$ glucose and $38 \%$ of xylose and arabinose conversion from a combined pretreatment of miscanthus in a twin screw extruder (100 rpm and $100^{\circ} \mathrm{C}$ ) and alkali $\left(\mathrm{NaOH} 12 \%\right.$ and $\left.70^{\circ} \mathrm{C}\right)$. It is a fact that higher alkali concentration not only removes the lignin but also degrades the carbohydrates. Hence, the low sugar recovery reported for miscanthus might be due to degradation of carbohydrates and the inherent characteristics of biomass. The retention of carbohydrates depends on the feedstock composition as evident from the ammonia pretreatment of corn stover and poplar (Gupta et al., 2007). Recently, Lee et al (2009) extruded Douglas fir using a twin screw extruder at 50 $\mathrm{rpm}$ and $40^{\circ} \mathrm{C}$ and reported cellulose to glucose conversion of $62.4 \%$ when ethylene glycol was added as a cellulose affinity additive. The difference in glucose recovery might be due to delignification, type of extruder, pretreatment conditions (as screw speed, temperature, and particle size), and the inherent characteristics of biomasses. Jung et al (1992) achieved $1.85,1.73$, and 1.58 times higher glucose, xylose, and arabinose recovery, respectively, when maize stalk was pretreated with $1 \mathrm{M} \mathrm{NaOH}$ at $39^{\circ} \mathrm{C}$ for $24 \mathrm{~h}$ followed by $72 \mathrm{~h}$ in vitro degradability compared to control sample. These authors reported a delignification of $62 \%$ for the above pretreatment condition.

A comprehensive comparison of various pretreatment methods employed on corn stover is listed in Table 4. It could be observed from the table that dilute acid (Yan et al., 2009), maleic acid (Lu \& Mosier, 2008), lactic and/ acetic acid (Xu et al., 2009), controlled pH hot water (Mosier et al., 2005), steam (Bura et al., 2009), and steam explosion (Elander et al., 2009) had comparable yield of this extrusion pretreatment. The present results were higher than dilute sulfuric acid (Chen et al., 2009; Zhu et al., 2009), formic acid (Xu et al., 2009a), soaking in ethanol and aqueous ammonia (Kim et al., 2009), and steam explosion (Mosier et al., 2005); however, it was lower than dilute acid (Zhu et al., 2005), inorganic salt- $\mathrm{FeCl}_{3}$ (Liu et al., 2009), cellulose solvent and organic solvent based lignocelluloses fractionation (Zhu et al., 2009). It could be noted that the particle size of corn stover used in most of the pretreatment listed in the table was lower than the extrusion pretreatment, and the higher enzyme dose was employed. Moreover, extrusion has an added advantage as a continuous process, wherein additions of chemicals are easy as demonstrated by by Dale et al (1999), de Vrije et al (2002), and Lee et al (2009). 


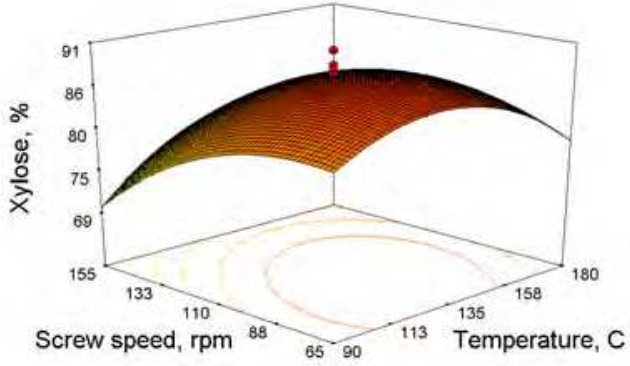

(a)

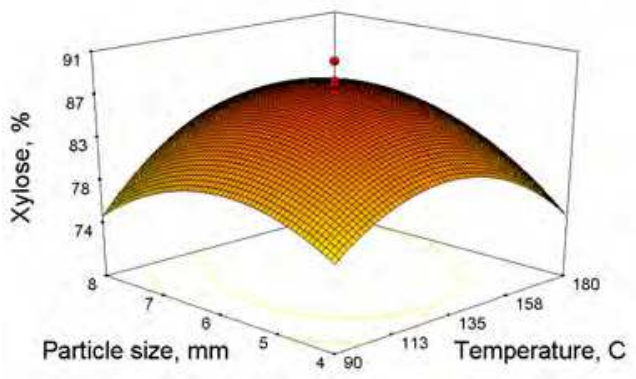

(c)

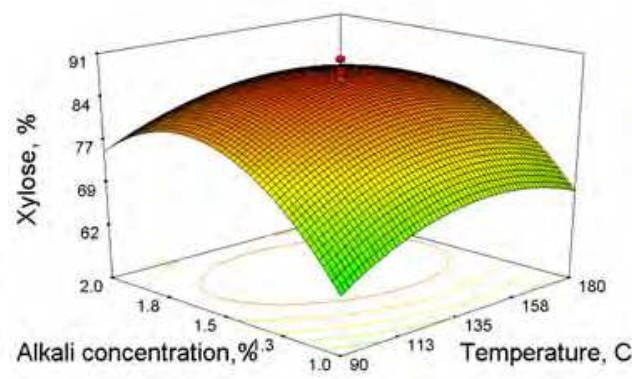

(b)

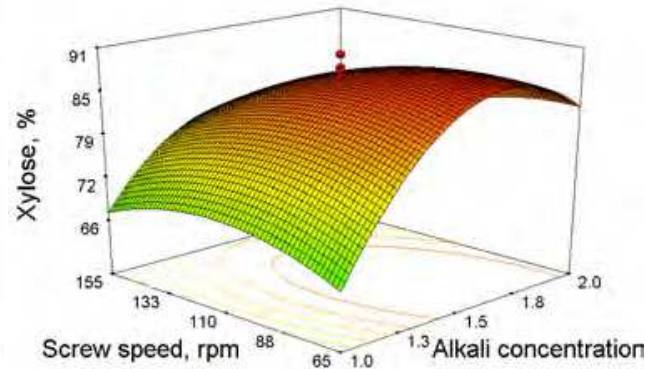

(d)

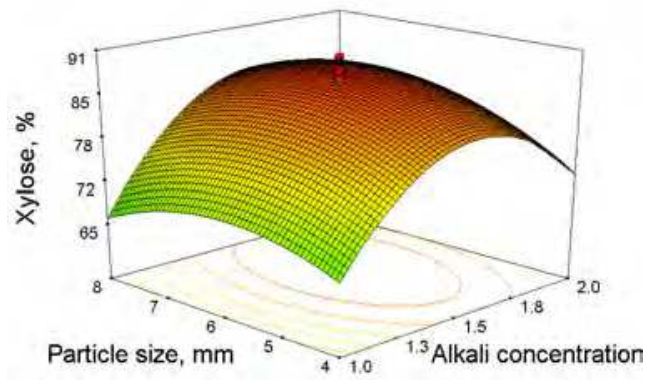

(e)

Fig. 2. Interaction effect of two independent variables on xylose recovery from corn stover (when other factors fixed at the center point: $135^{\circ} \mathrm{C}, 110, \mathrm{rpm}, 1.5 \% \mathrm{w} / \mathrm{w}$, and $6 \mathrm{~mm}$ ) 


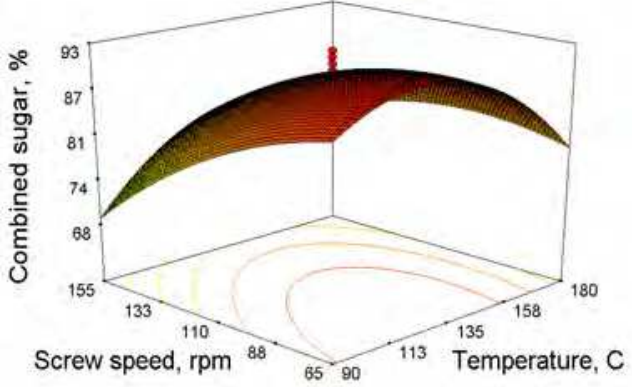

(a)

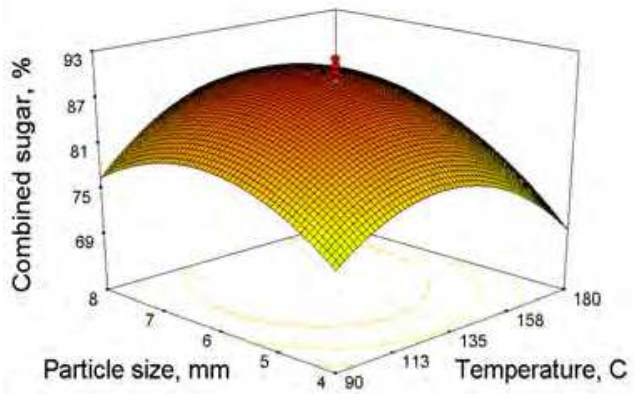

(c)

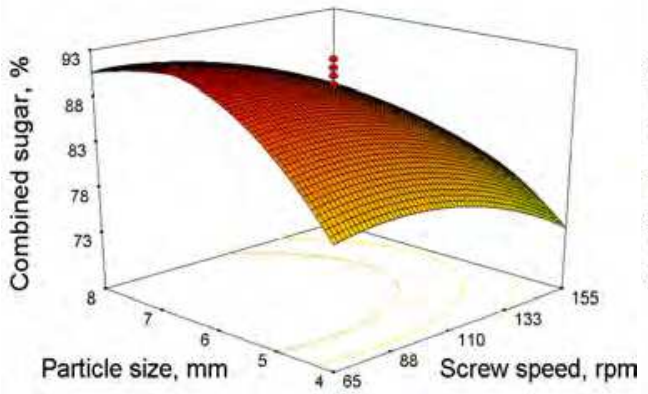

(e)

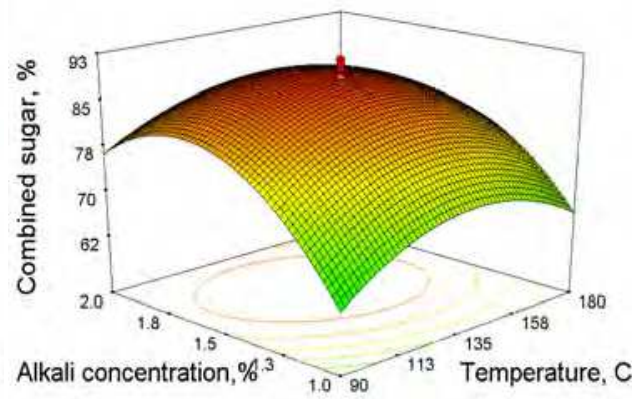

(b)

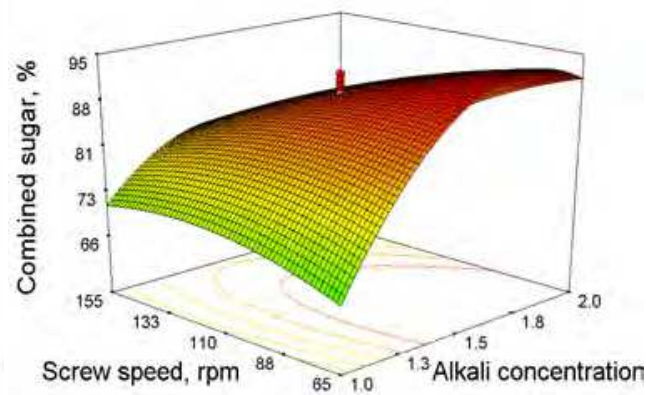

(d)

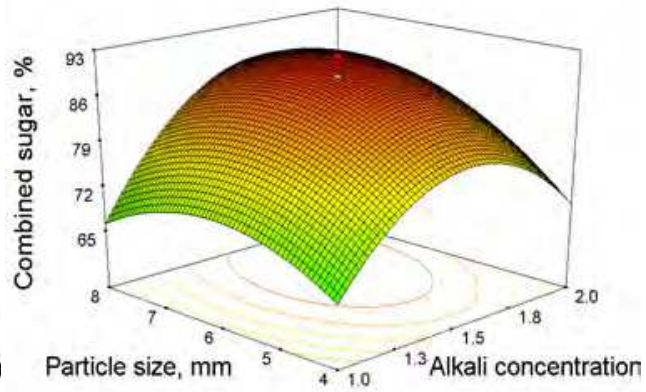

(f)

Fig. 3. Interaction effect of two independent variables on combined sugar recovery from corn stover (when other factors fixed at the center point: $135^{\circ} \mathrm{C}, 110, \mathrm{rpm}, 1.5 \% \mathrm{w} / \mathrm{w}$, and 6 $\mathrm{mm})$ 
Corn stover was subjected to several pretreatment methods such as dilute acid, alkali, wet oxidation, hot water, steam, steam explosion, ammonia recycle percolation, and AFEX as found in literature. Table 1 shows different alkalis employed on corn stover and their pretreatment conditions along with glucose and xylose recovery. Although large corn stover particles was used in the present study, the glucose and xylose recovery obtained in this study was comparable with most of the alkali pretreatments listed in the table. However, the result of present study was higher than the values reported for alkali (Varga et al., 2002), wet oxidation (Varga et al., 2003), aqueous ammonia soaking pretreatment (Kim \& Lee, 2007), lime and alkali pretreatment (Chen et al., 2009). Rodgers et al (2009) achieved higher glucose and xylose yield than the current study.

The sugar recovery obtained in the present study was comparable with that of the 88-93\% glucose reported for dilute acid pretreatment at $140^{\circ} \mathrm{C}$ with $0.98 \% \mathrm{H}_{2} \mathrm{SO}_{4}$ for $40 \mathrm{~min}$ (Lloyd \& Wyman, 2005), more than 95\% glucose and 77\% xylose from the dilute acid percolation process at $180^{\circ} \mathrm{C}$ with $1 \%$ acid $(\mathrm{w} / \mathrm{w})$ at a flow rate of $10 \mathrm{~mL} / \mathrm{min}$ for $3 \mathrm{~min}$, followed by $\mathrm{N}_{2}$ through quenching (Zhu et al., 2004). Varga et al (2002) obtained 95.7\% glucose when corn stover was pretreated with $1 \% \mathrm{NaOH}$ for a day followed by a $60 \mathrm{~min}$ autoclaving with $1 \%$ $\mathrm{H}_{2} \mathrm{SO}_{4}$. A similar result was reported from compressed hot water pretreatment of corn stover at $200^{\circ} \mathrm{C}$ with a flow rate of $10 \mathrm{~mL} / \mathrm{min}$ for $24 \mathrm{~min}$ (Liu \& Wyman, 2005). The difference in sugar recovery might be due to the mechanisms of different pretreatment methods, the pretreatment conditions employed, and the composition of raw corn stover.

\subsection{Response surface model evaluation}

The predicted and observed responses along with coded and actual variables are presented in Table 2. The closeness of the predicted and observed responses reflects the goodness of fit. The analysis of variance of the observed data, $p$ value $(\alpha=0.05)$ and the coefficient of determination $\left(\mathrm{R}^{2}\right)$ of the regression model using CCRD are presented in Table 5 . The $F$ value for the glucose, xylose, and combined sugar were very high compared to the tabular $\mathrm{F}_{14,21}$ value of 2.19 indicates that the model was highly significant. As noted from the table that the regression model was significant, whereas the lack of fit was not significant, suggested that proposed model is good. The fact that the coefficient of determination was also close to one reflects the adequacy of the model to represent relationship among the barrel temperature, screw speed, alkali concentration, and particle size on sugar recovery. However, a large value of $\mathrm{R}^{2}$ does not always imply that the regression model is a good one because $\mathrm{R}^{2}$ will increase when a variable is added regardless of whether the additional variable is statistically significant or not (Xin \& Saka, 2008). Hence, adjusted and predicted $\mathrm{R}^{2}$ were calculated to check the model adequacy.

The predicted determination coefficient was in reasonable agreement with the adjusted determination coefficient and it also confirms the fitness of the model. The proposed models explain more than $90 \%$ of the variations in sugar recoveries. Coefficient of variation $(\mathrm{CV})$ is the ratio of standard error estimate to the mean values expressed as percentage and is another measure to evaluate the goodness of the model. As a general rule, the CV should not be greater than 10\% (Cocharan \& Cox, 1957; Linko et al., 1984; Vainionpaa \& Malkki, 1987). Considering the general rule, a low value of CV $(2.68-3.20 \%)$ shows that the experiments conducted are precise and reliable. "Adeq Precision" measures the signal-tonoise ratio. The larger the ratio, better the prediction/optimization; in general, a ratio greater than 4 is desirable. The ratio of 38.69-57.38 indicates an adequate signal thus, the model can be used to navigate the design space (Liu et al., 2010). 


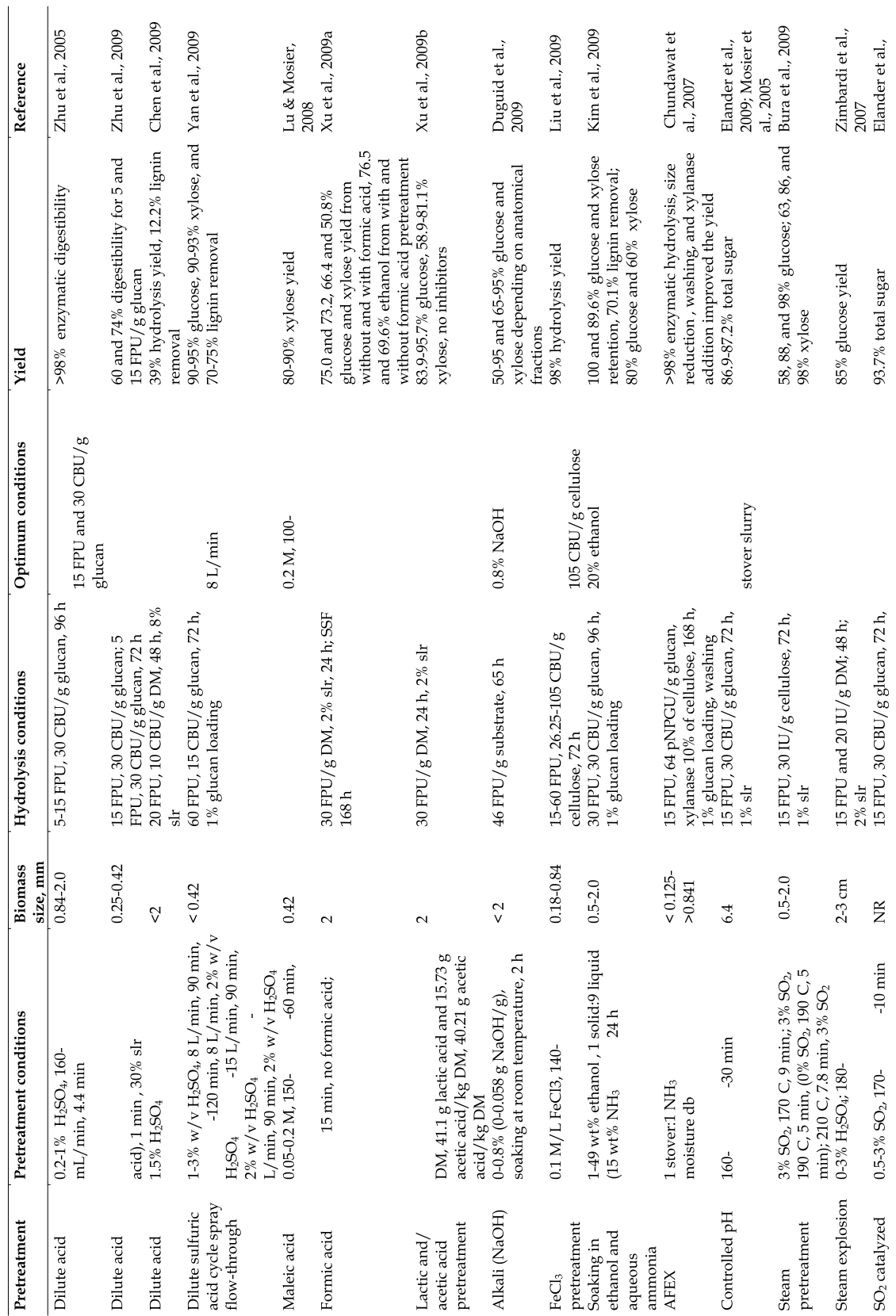

slr-solids loading rate DM- dry matter

Table 4. Pretreatment and hydrolysis conditions employed on corn stover pretreated in different pretreatment methods 


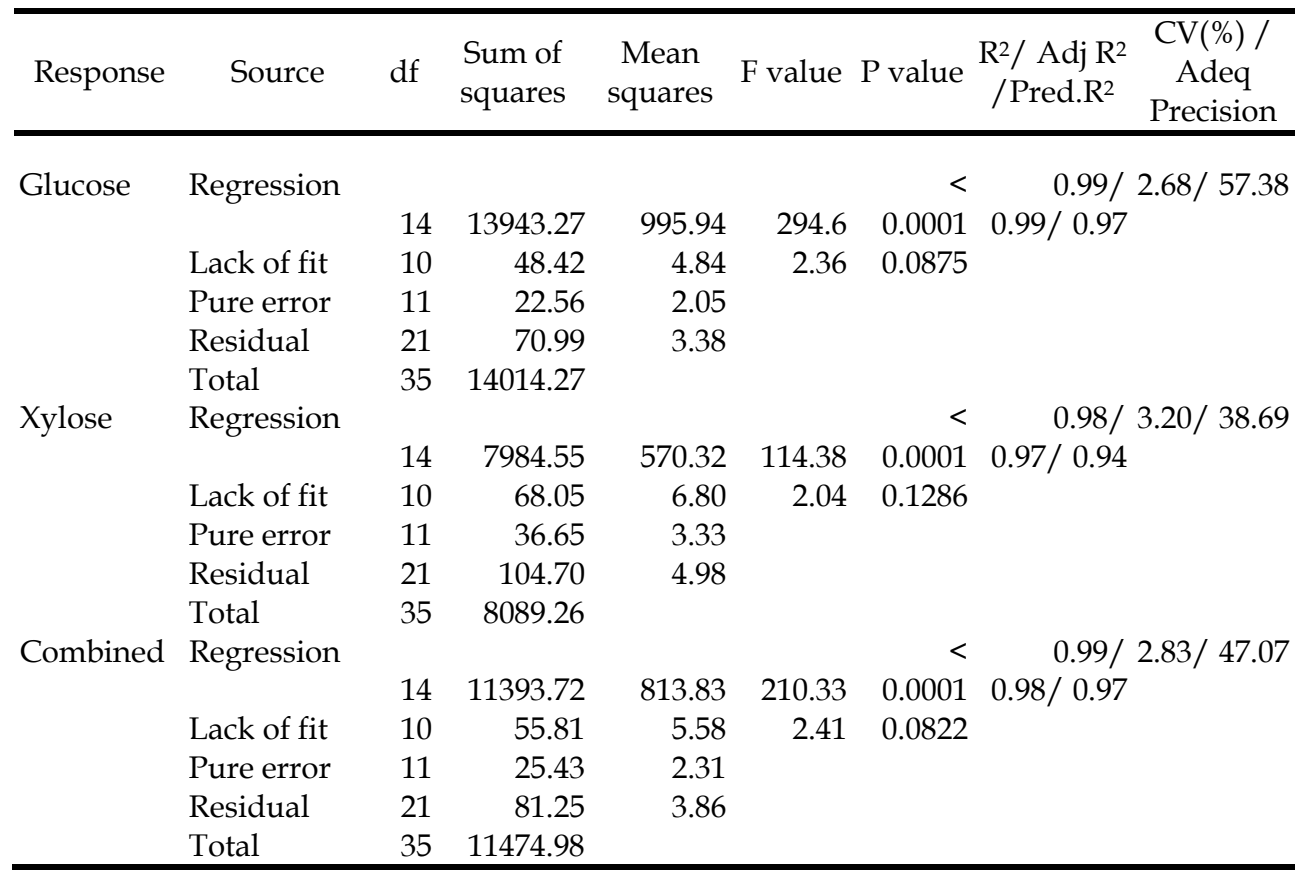

Table 5. Analysis of variance of the fitted model for different responses

\subsection{Optimization and validation}

The interactions discussed in the previous section were for individual sugar recovery. Maximum glucose, xylose, and combined sugar recovery were the desirable responses considered for optimization. Hence, an overlay contour plots superimposing glucose, xylose, and combined sugar recovery responses were depicted in Fig. 4. The shaded region gave wide range of options to select the barrel temperature $\left(90-180^{\circ} \mathrm{C}\right)$, screw speed $(50-155$ rpm), alkali concentration (1.25-2.0\%), and particle size (4-9 $\mathrm{mm}$ ) for maximum glucose (80$95 \%)$, xylose (80-95\%), and combined sugar (80-90\%) recovery from corn stover. Based on the models, numerical optimization was carried out in Design Expert. Considering each response, three solutions were found as shown in Table 6 . In order to confirm the predicted responses, corn stover was extruded at a barrel temperature of $133^{\circ} \mathrm{C}$, a screw speed of 85 $\mathrm{rpm}$ and $1.65 \%$ alkali concentration with two different particle sizes since the optimum particle size was $6.45 \mathrm{~mm}$, which is in between 6 and $8 \mathrm{~mm}$. The extruded samples (Fig. 5) were subjected to the enzymatic hydrolysis and sugar measurement as described in the Materials and Methods.

The glucose, xylose, and combined sugar obtained were 91.8, 82.3, and 90.0\%, respectively; the values were very close to the predicted values; which was 5.0, 2.5, and 4.3 times higher than control sample. The sugar recovery comparison of control, alkali soaked, and alkali soaked - extruded corn stover is shown in Fig. 6 for better understanding. The alkali soaked corn stover had a double times sugar recovery of control, whereas the alkali soakedextrusion pretreated corn stover had double times that of alkali soaked corn stover as evident from Fig 6. A mass balance diagram is shown in Fig. 7 for better understanding 

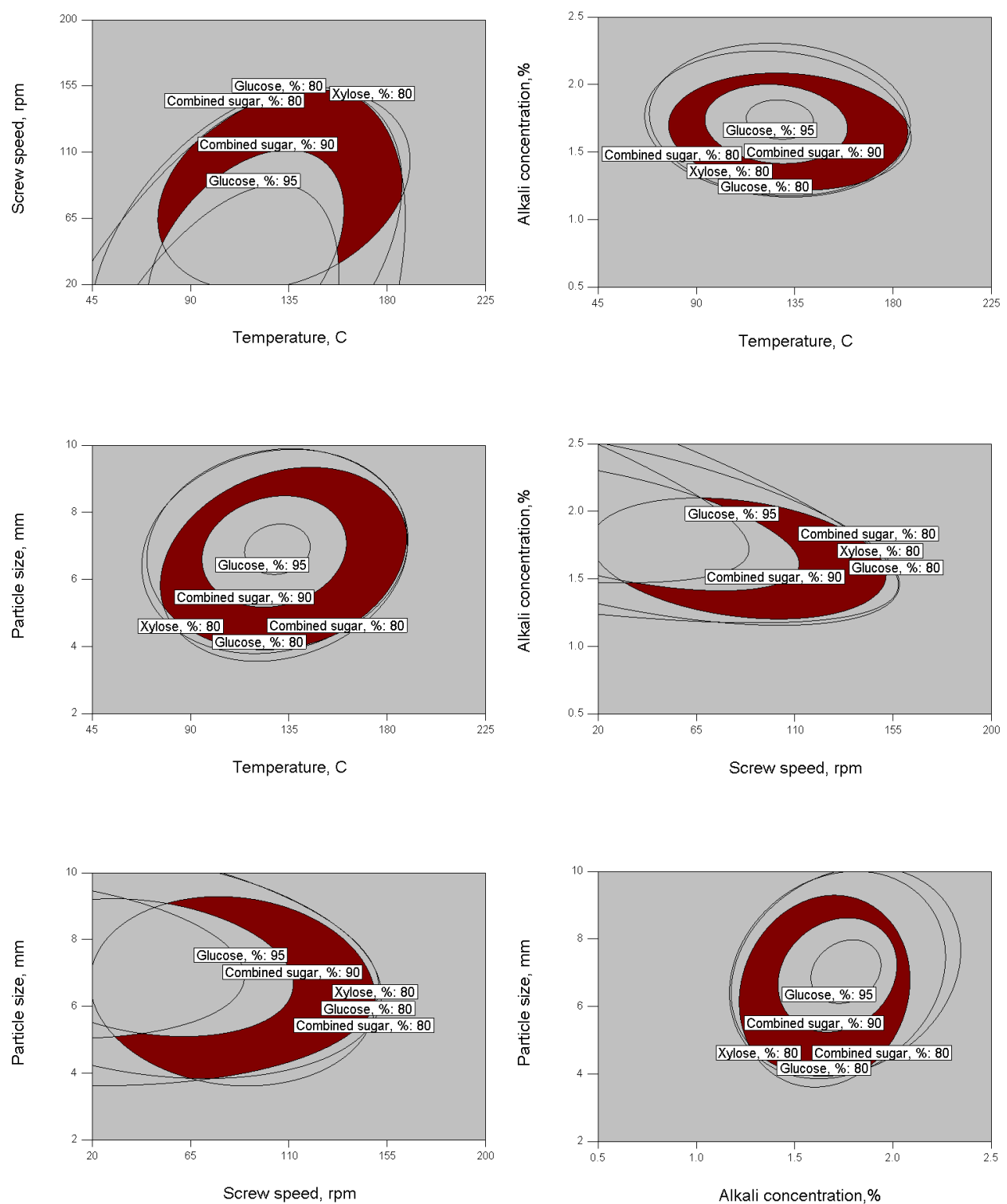

Fig. 4. Superimposed contours for sugar recovery responses as a function of temperature, screw speed, alkali concentration, and particle size of corn stover 


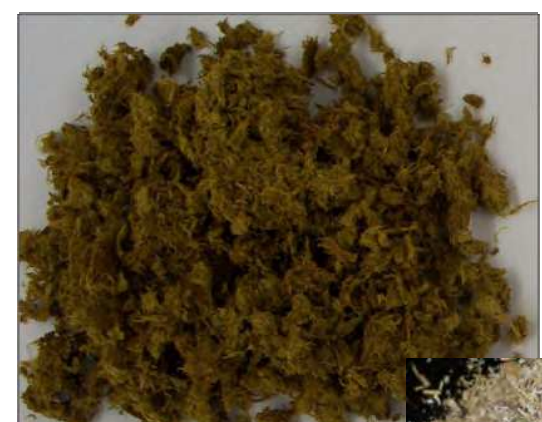

$133^{\circ} \mathrm{C}, 85 \mathrm{rpm}, 1.65 \% \mathrm{w} / \mathrm{v}, 6 \mathrm{~mm}$

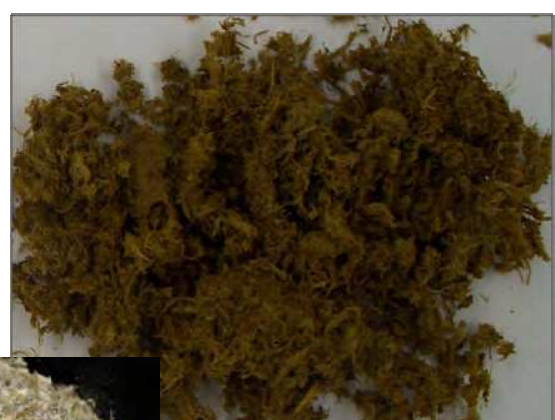

$133^{\circ} \mathrm{C}, 85 \mathrm{rpm}, 1.65 \% \mathrm{w} / \mathrm{v}, 8 \mathrm{~mm}$

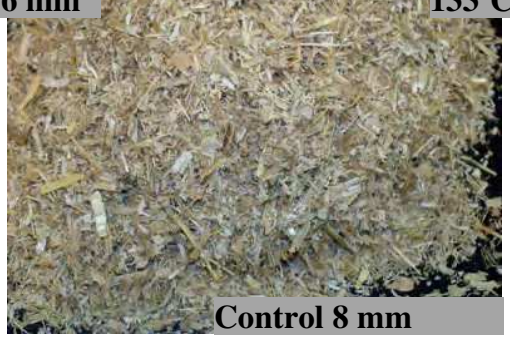

Fig. 5. Corn stover extruded at optimum pretreatment conditions for validation

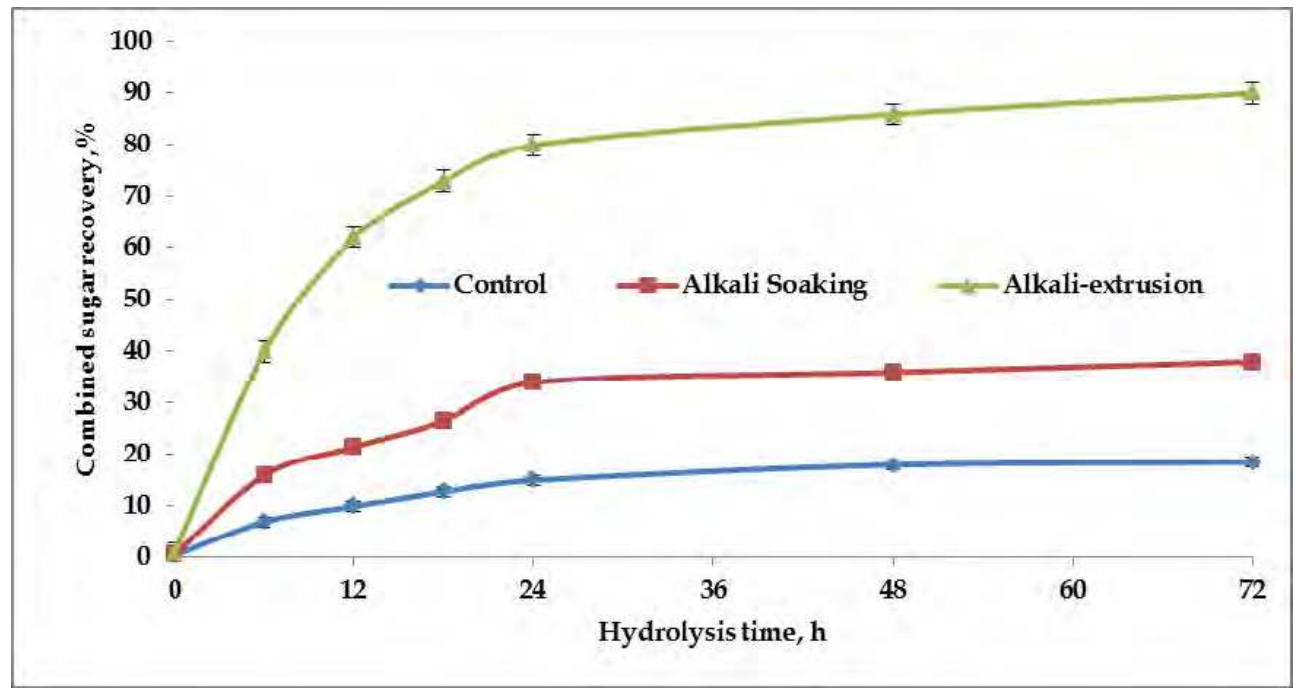

Fig. 6. Comparison of sugar recovery profile from control, alkali soaked, and alkali soakedextruded corn stover 


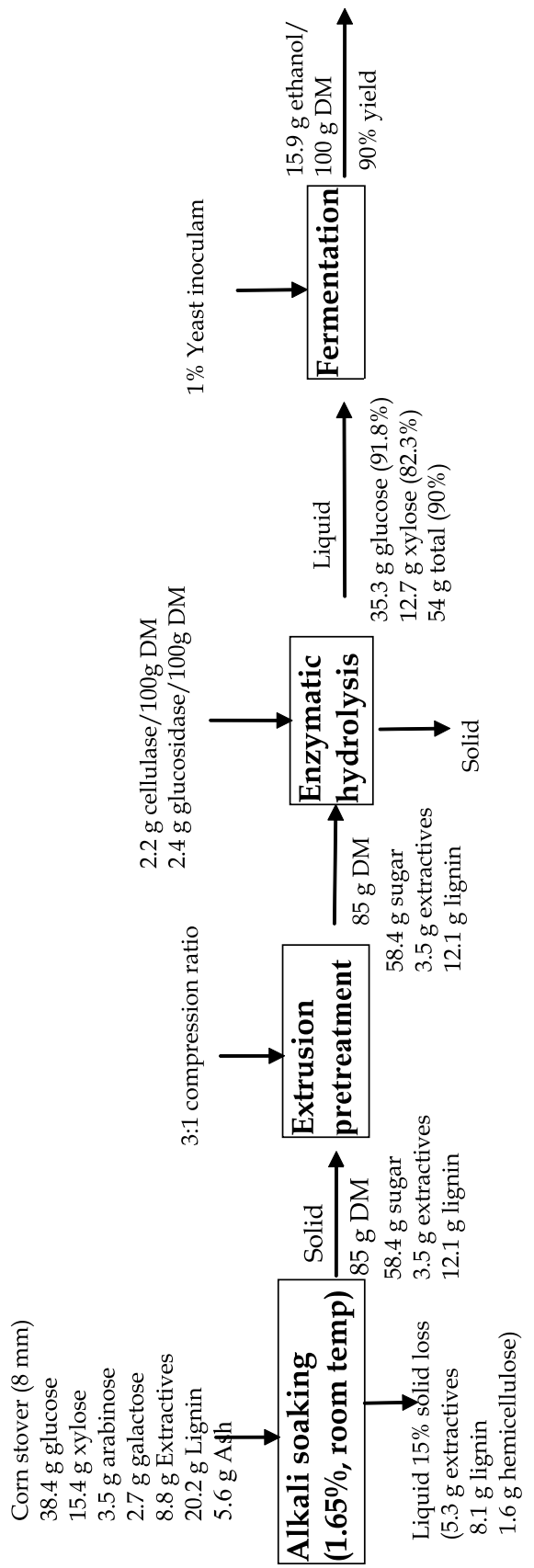

Fig. 7. Mass balance diagram of alkali soaking-extrusion pretreatment of prairie cord grass followed by fermentation 


\begin{tabular}{cccccccc}
\hline Solution \# & $\begin{array}{c}\text { Temperature, } \\
{ }^{\circ} \mathrm{C}\end{array}$ & $\begin{array}{c}\text { Screw } \\
\text { speed, } \\
\text { rpm }\end{array}$ & $\begin{array}{c}\text { Alkali } \\
\text { conc, } \\
\%\end{array}$ & $\begin{array}{c}\text { Particle } \\
\text { size, } \\
\mathrm{mm}\end{array}$ & $\begin{array}{c}\text { Glucose, } \\
\%\end{array}$ & $\begin{array}{c}\text { Xylose, } \\
\%\end{array}$ & $\begin{array}{c}\text { Combined } \\
\text { sugar, } \%\end{array}$ \\
\hline 1 & 133 & 84 & 1.65 & 6.45 & 95.61 & 88.73 & 93.89 \\
2 & 133 & 85 & 1.65 & 6.46 & 95.52 & 88.73 & 93.84 \\
3 & 133 & 84 & 1.65 & 6.44 & 95.68 & 88.73 & 93.94 \\
Validation & & & & & & & \\
& 133 & 85 & 1.65 & 6 & 92.65 & 86.59 & 90.53 \\
& 133 & 85 & 1.65 & 8 & 91.76 & 86.26 & 90.08 \\
\hline
\end{tabular}

Table 6. Solutions for optimal and validation conditions

(assumption a thumb rule is $50 \%$ of the glucose will be converted into ethanol during fermentation with an efficiency of $90 \%$ ).This optimization study revealed that a larger particle size $(8 \mathrm{~mm})$ could be used for biofuels production; thereby the biomass size reduction energy cost can be saved to a greater extent.

Although the optimum pretreatment condition differed from corn stover, similar sugar recovery was reported for switchgrass and prairie cord grass (Karunanithy \& Muthukumarappan, 2011b, 2011c). The biomass digestibility depends on the specific types of phenolic acids that constitute the non-core lignin of lignocellulosic biomass (Jung \& Deetz, 1993). These phenolic acids are involved in the ester linkages between hemicellulose and lignin. The major non-core lignin phenolic acids are pcoumaric acid (CA) and ferulic acid (FA). According to Burritt et al (Burritt et al., 1984) and Jung (1989), the ratio of CA to FA present in non-core lignin has a strong negative impact on biomass digestibility. The difference in alkali concentration might be attributed to their pcoumaric to ferulic acids ratio apart from lignin content. The glucose, xylose, and combined sugar recovery of 90.5, 81.5, and $88 \%$, respectively, were reported for the optimum pretreatment conditions of $180^{\circ} \mathrm{C}$ barrel temperature, $118 \mathrm{rpm}$ screw speed, $2 \%$ alkali concentration, and $6 \mathrm{~mm}$ switchgrass particle size. The optimum pretreatment conditions of $114^{\circ} \mathrm{C}$ barrel temperature, $122 \mathrm{rpm}$ screw speed, $1.70 \%$ alkali concentration, and $8 \mathrm{~mm}$ particle size of prairie cord grass resulted in a glucose, xylose, and combined sugar recovery of 87,85 , and $82 \%$, respectively. The difference in sugar recovery and optimum conditions might be attributed to the inherent nature of biomasses including their chemical compositions.

\subsection{Byproducts formation}

In general, furfural, HMF, and acetic acid are the fermentation inhibitors found in most of the pretreatment at different extent for various feedstocks as listed in Table 7. Pretreatment temperature, residence time, and acid concentration are the important factors influence the degradation process; moreover the degradation is proportional to the pretreatment severities (Bustos et al., 2003; Hodge et al., 2008; Rodríguez et al., 2009; Sassner et al., 2008; Yu et al., 2010; Zeng et al., 2007). When side chains of acetyl group present in hemicellulose are released, acetic acid is generated. Various researchers reported a range of $1.9-7.3 \%$ acetyl group for corn stover (Balan et al., 2009; Kim \& Lee, 2005b; Torget et al., 1991; Weiss et al., 2009). Acetic acid was the only byproduct found in most of the pretreated corn stover samples in the range of $0.060-0.168 \mathrm{~g} / \mathrm{L}$. The highest acetic acid $(0.168 \mathrm{~g} / \mathrm{L})$ resulted at a 


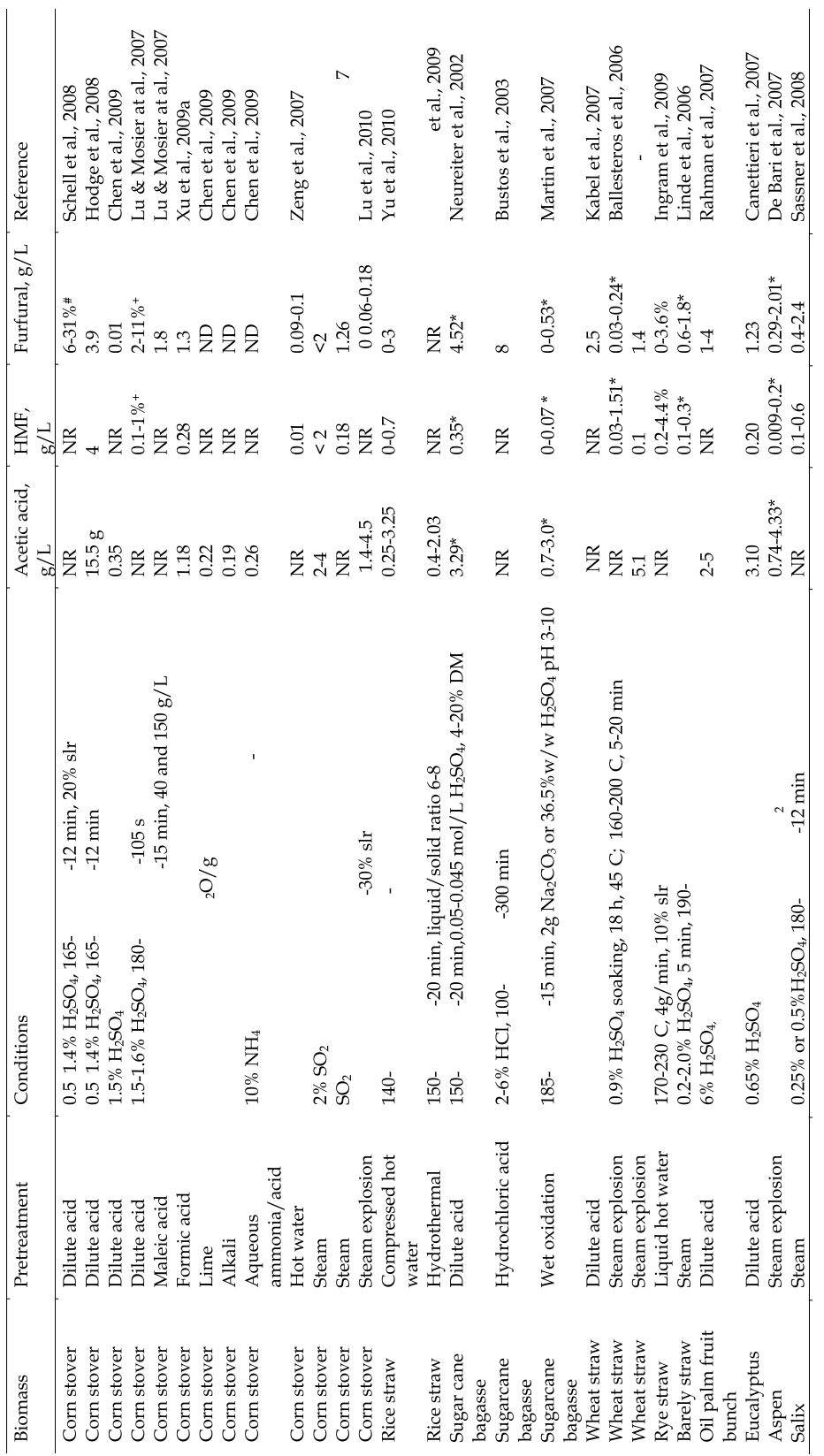

\# furfural yield ${ }^{*} \mathrm{~g} / 100 \mathrm{~g}$ + loss of respective sugar slr- solids loading rate NR- not reported ND- not detected DM- dry matter

Table 7. Comparison of inhibitor formation from different feedstocks produced through various pretreatments 
barrel temperature of $135^{\circ} \mathrm{C}$ and a screw speed of $110 \mathrm{rpm}$, alkali concentration of $1.5 \%$ and a particle size of $6 \mathrm{~mm}$. It was noticed that acetic acid concentration was $0.143 \mathrm{~g} / \mathrm{L}$ for the optimized conditions $\left(133^{\circ} \mathrm{C}, 85 \mathrm{rpm}, 1.65 \%\right.$, and $\left.8 \mathrm{~mm}\right)$. The acetic acid formation and its concentration confirmed that the deacetylzation process, however the concentration was below the inhibition limit (Taherzadeh et al., 1997). The particle size of rice straw and silvergrass inversely influenced the acetic acid formation in dilute acid pretreatment (Guo et al., 2008); however, it was not confirmed in this study.

The acetic acid concentration was lower than dilute acid (Chen et al., 2009; Hodge et al., 2008), formic acid (Xu et al., 2009a), lime (Chen et al., 2009), alkali (Chen et al., 2009), hydrothermal pretreatment (Öhgren et al., 2006; Lu et al., 2010) of corn stover; compared to other feedstocks listed in the table. $\mathrm{NaOH}$ has higher reactivity with hemicellulose than cellulose due to amorphous characteristics of hemicellulose (Lai, 2001). In addition, Gupta (2008) reported that minimum loss of hemicellulose is unavoidable for corn stover pretreated with dilute $\mathrm{NaOH}(1-5 \%)$ at $60^{\circ} \mathrm{C}$ for $24 \mathrm{~h}$. However, the mild pretreatment condition $\left(25^{\circ} \mathrm{C}, 1 \% \mathrm{NaOH}, 24 \mathrm{~h}\right)$ minimized the sugar loss from corn stover (Gupta, 2008). No glycerol was found in any of the pretreatment combinations in contrary to the results reported by Karunanithy and Muthukumarappan (Karunanithy \& Muthukumarappan, 2010c, 2011a, 2011b, 2011c, 2010a, 2010b).In addition, no furfural and HMF were found in any of the pretreated corn stover samples. The possible reason could be short residence time and no acidic conditions during pretreatment as compared most of the pretreatment methods listed in the table.

\section{Conclusions}

Corn stover was extruded using a single screw extruder at various conditions based on a central composite rotatable design to obtain maximum glucose, xylose, arabinose, and combined sugar recovery. Statistical analyses confirmed that extruder barrel temperature, screw speed, alkali concentration, and particle size had a significant effect on sugar recovery. Response surface methodology was adopted to optimize alkali concentration, corn stover particle size, and extruder parameters for maximum sugar recovery. The proposed quadratic model to predict the sugar recovery had high $\mathrm{F}$ and $\mathrm{R}^{2}$ values with low $\mathrm{p}$ value represents an adequate relationship among the independent variables studied on sugar recovery from corn stover. It was found that under optimum condition such as barrel temperature of $133^{\circ} \mathrm{C}$, screw speed of $85 \mathrm{rpm}$, alkali concentration of $1.65 \% \mathrm{w} / \mathrm{v}$ with $8 \mathrm{~mm}$ particle size, the glucose, xylose, and combined sugar recovery were $91.8,82.3$, and $90.1 \%$, respectively, and also confirmed through validation. This optimization study revealed that larger corn stover particle $(8 \mathrm{~mm})$ can be used for biofuels production, which could result in saving of size reduction energy cost.

\section{Acknowledgements}

This research was supported by funding from the Agricultural Experiment Station and North Central Sun Grant Center at South Dakota State University through a grant provided by the US Department of Transportation, Office of the Secretary, Grant No.DTOS59-07-G00054. Also, enzymes supplied by Novozymes, Inc for conducting this study were greatly appreciated. 


\section{References}

Altan, A., McCarthy, KL., \& Maskan, M. (2008). Twin-screw extrusion of barley-grape pomace blends: Extrudate characteristics and determination of optimum processing conditions. J Food Eng., 89, 24-32, 0260-8774

Balan, V., da Costa Sousa, L., Chundawat, SPS., Marshall, D., Sharma, LN., Chambliss, CK., \& Dale, BE. (2009). Enzymatic digestibility and pretreatment degradation products of AFEX-treated hardwoods (Populus nigra). Biotechnol. Prog., 25, 2, 365-375, 15206033

Ballesteros, I., Negro, MJ., Oliva, JM., Cabañas, A., Manzanares, P., \& Ballesteros, M. (2006). Ethanol production from steam-explosion pretreated wheat straw. Appl. Biochem. Biotechnol., 130, 1-3, 496-508, 0273-2289

Bura, R., Chandra, R., \& Saddler, J. (2009). Influence of xylan on the enzymatic hydrolysis of steam-pretreated corn stover and hybrid poplar. Biotechnol. Prog. 25, 2, 315-322, 1520-6033

Burritt, EA., Bittner, AS., Street, JC., \& Anderson, MJ. (1984). Correlations of phenolic-acids and xylose content of cell-wall with in vitro dry-matter digestibility of 3 maturing grasses. J Dairy Sci., 67, 6, 1209-1213, 0022-0302

Bustos, G., Ramírez, JA., Garrote, G., \& Vázquez, M. (2003). Modeling of the hydrolysis of sugar cane bagasse with hydrochloric acid. Appl. Biochem. Biotechnol., 104, 52-69, 0273-2289

Cadoche, L., \& Lopez, GD. (1989). Assessment of size reduction as a preliminary step in the production of ethanol from lignocellulosic wastes. Biolog. Wastes, 30, 153-157, 02697483

Canettieri, EV., Rocha, GJM., Carvalho Jr, JA., \& Silva, JBA. (2007). Optimization of acid hydrolysis from the hemicellulosic fraction of Eucalyptus grandis residue using response surface methodology. Bioresour. Technol., 98, 422-428, 0960-8524

Chang, VS., Nagwani, M., Kim, C-H., \& Holtzapple, MT. (2001). Oxidative lime pretreatment of high-lignin biomass poplar wood and newspaper. Appl. Biochem. Biotechnol., 94,1-28, 0273-2289

Chen, FL., Wei, YM., Zhang, B., \& Ojokoh, AO. (2010). System parameters and product properties response of soybean protein extruded at wide moisture range. $J$ Food Eng., 96, 208-213, 0260-8774

Chen, M., Zhao, J., \& Xia, L. (2009). Comparison of four different chemical pretreatments of corn stover for enhancing enzymatic digestibility. Biomass Bioenerg., 33, 10,13811385, 0961-9534

Chundawat, SPS., Venkatesh, B., \& Dale, BE. (2007). Effect of particle size based separation of milled corn stover on AFEX pretreatment and enzymatic digestibility. Biotechnol. Bioeng., 96, 2, 219-231, 1097-0290

Cocharan, WG., \& Cox, GM. (1957). In Experimental Designs, Bradley RA, Kendall DG, Hunter JS, Watson GS (eds). Wiley: New York, pp. 335-375

Crofcheck, CL., \& Montross, MD. (2004). Effect of stover fraction on glucose production using enzymatic hydrolysis. Transactions of the ASAE, 47, 3, 841-844, 0001-2351

Dale, BE., Weaver, J., \& Byers ,FM. (1999). Extrusion processing for ammonia fiber explosion (AFEX). Appl. Biochem. Biotechnol., 77,35-45, 0273-2289

Dawson, L., \& Boopathy, R. (2007). Use of post-harvest sugarcane residue for ethanol production. Bioresour. Technol., 98, 9, 1695-1699, 0960-8524 
De Bari, I., Nanna, F., \& Braccio, G. (2007). $\mathrm{SO}_{2}$-catalyzed steam fractionation of aspen chips for bioethanol production: Optimization of the catalyst impregnation. Ind. Eng. Chem. Res., 46, 23, 7711-7720, 0088- 5885

de Leon, N., \& Coors, JG. (2008). Chapter 7: Genetic improvement of corn for lignocellulosic feedstock production, In: Genetic Improvement of Bioenergy Crops, W. Vermerris (ed.), pp.185-210. Springer Science, 978-0-387-70804-1, New York

Desari, RK., \& Bersin, RE. (2007). The effect of particle size on hydrolysis reaction rates and rheological properties in cellulosic slurries. Appl. Biochem. Biotechnol., 136-140, 289299, 0273-2289

Design Expert 7.1.6. Statease, Minneapolis, MN, 2002.

de Vrije, T., de Haas, GG., Tan, GB., Keijsers, ERP., \& Claassen, PAM. (2002). Pretreatment of miscanthus for hydrogen production by thermotoga elfii. Inter. J Hydrogen Energy, 27, 1381-1390, 0360-3199

Duguid, KB., Montross, MD., Radtke, CW., Crofcheck, CL., Wendt, LM., \& Shearer SA. (2009). Effect of anatomical fractionation on the enzymatic hydrolysis of acid and alkaline pretreated corn stover. Bioresour. Technol., 100, 21, 5189-5195, 0960-8524

Elander, RT., Dale, BE., Holtzapple, M., Ladisch, MR., Lee, YY., Mitchinson, C., Saddler, JN., \& Wyman, CE. (2009). Summary of findings from the Biomass Refining Consortium for Applied Fundamentals and Innovation (CAFI): Corn stover pretreatment. Cellulose, 16, 4, 649-659, 1572-882X

Elshafei, AM., Vega ,JL., Klasson, KT., Clausen, E., \& Gaddy, JL.(1991). The saccharification of corn stover by cellulase from Penicillinfuniculosum. Bioresour. Technol., 35, 73-80, 0960-8524

Gibbons, WR., Westby, CA., \& Dobbs, TL. (1986). Intermediate-scale, semicontinuous solidphase fermentation process for production of fuel ethanol from sweet sorghum. Appl. Environ. Microbiol., 51,1, 115-122, 0099-2240

Guo, G-L., Chen, W-H., Chen, W-H., Men, L-C., \& Hwang, W-S. (2008). Characterization of dilute acid pretreatment of silvergrass for ethanol production. Bioresour. Technol., 99, 14, 6046-6053, 0960-8524

Gupta, R. (2008).Alkaline pretreatment of biomass for ethanol production and understanding the factors influencing the cellulose hydrolysis. Ph.D Dissertation, Auburn University, Alabama

Gupta, R., Kim, TH., \& Lee, YY. (2007). Substrate dependency and effect of xylanase supplementation on enzymatic hydrolysis of ammonia-treated biomass. Appl. Biochem. Biotechnol., 148,1-3, 59-70, 0273-2289

Hayashi, N., Hayakawa, I., \& Fujio, Y. (1992). Hydration of heat-treated soy protein isolate and its effect on the molten flow properties at an elevated temperature. Inter. J Food Sci. Technol., 27, 565-571, 1365-2621

Hodge, DB., Karim, MN., Schell, DJ., \& McMillan, JD. (2008). Soluble and insoluble solids contributions to high-solids enzymatic hydrolysis of lignocelluloses. Bioresour. Technol., 99, 18, 8940-8948, 0960-8524

$\mathrm{Hu}, \mathrm{Z}$. , Wang, Y., \& Wen, Z.(2008). Alkali (NaOH) pretreatment of switchgrass by radio frequency-based dielectric heating. Appl. Biochem. Biotechnol. 148, 71-81, 0273-2289

Ingram, T., Rogalinski, T., Bockemühl, V., Antranikian, G., \& Brunner, G. (2009). Semicontinuous liquid hot water pretreatment of rye straw. J Supercritical Fluids, 48, 3, 238-246, 0896-8446 
Jorge, M., Roberto, G., Karina, PJX., Oliva, CE., Benjamin, R., \& Cuauhte'́mocc, R. (2006).The optimization of the extrusion process when using maize flour with a modified amino acid profile for making tortillas. Inter. J Food Sci. Technol. 41, 727-736, 13652621

Jung , HG. (1989). Forage lignins and their effects on fiber digestibility. Agron. J., 81, 1, 33-38, 0002-1962

Jung, HG., \& Deetz, DA. (1993). Cell wall lignification and degradability. p. 315-346. In H.G. Jung et al (ed.) Forage cell wall structure and digestibility. ASA, CSSA, and SSSA, Madison, WI, 0891181156

Jung, HG., Valdez, FR., Hatfield, RD., \& Blanchette, RA.(1992). Cell wall composition and degradability of forage stems following chemical and biological delignification. $J$ Sci. Food Agric., 58, 347-355, 1097-0010

Kaar, W., \& Holtzapple, M. (2000). Using lime pretreatment to facilitate the enzymatic hydrolysis of corn stover. Biomass Bioenerg., 18, 3, 189-199, 0961-9534

Kabel, MA., Bos, G., Zeevalking, J., Voragen, AGJ., \& Schols, HA. (2007). Effect of pretreatment severity on xylan solubility and enzymatic breakdown of the remaining cellulose from wheat straw. Bioresour. Technol., 98, 10, 2034-2042, 09608524

Kadam, KL, \& McMillan, JD. (2003). Availability of corn stover as a sustainable feedstock for bio-ethanol production. Bioresour. Technol., 88, 17-25, 0960-8524

Karunanithy, C., Muthukumarappan, K., \& Julson, JL. (2008). Influence of high shear bioreactor parameters on carbohydrate release from different biomasses. ASABE Paper No. 084109. St. Joseph, Mich.: ASABE

Karunanithy, C., \& Muthukumarappan, K. (2010a).Effect of extruder parameters and moisture content of corn stover and big bluestem on sugar recovery from enzymatic hydrolysis. Biolog Engg., 2, 2,91-113, 1934-2799

Karunanithy, C., \& Muthukumarappan, K. (2010b). Influence of extruder temperature and screw speed on pretreatment of corn stover while varying enzymes and their ratios. Appl. Biochem. Biotechnol., 162, 264-279, 0273-2289

Karunanithy, C., \& Muthukumarappan, K. 2010c. Effect of extruder parameters and moisture content of switchgrass, prairie cord grass on sugar recovery from enzymatic hydrolysis. Appl. Biochem. Biotechnol. 162, 1785-1803, 0273-2289

Karunanithy, C., \& Muthukumarappan, K. (2011a). Optimization of corn stover and extruder parameters for enzymatic hydrolysis using respons surface methodology. Biological Engg, 3(2), 73-95, 1934-2799

Karunanithy, C., \& Muthukumarappan, K. (2011b). Optimization of alkali concentration, switchgrass particle size and extruder parameters for maximum sugar recovery using response surface methodology. Chemical Engg \& Tech.,(Accepted), 1521-4125

Karunanithy, C., \& Muthukumarappan, K. (2011c). Optimization of alkali concentration and extruder parameters for maximum sugar recovery from prairie cord grass using response surface methodology. Biochemical Engg J., DOI:10.1016/j.bej.2011.02.001, 1369-703X

Keshwani, DR. (2009). Microwave pretreatment of switchgrass for bioethanol production. PhD dissertation, North Carolina State University, Raleigh, North Carolina

Kim, JW., \& Mazza, G. (2008). Optimization of phosphoric acid catalyzed fractionation and enzymatic digestibility of flax shives. Ind. Crops Prod., 28, 346-355, 0926-6690 
Kim, S., \& Holtzapple, MT. (2005). Lime pretreatment and enzymatic hydrolysis of corn stover. Bioresour. Technol., 96,18, 1994-2006, 0960-8524

Kim, SB., \& Lee, YY. (2002). Diffusion of sulfuric acid within lignocellulosic biomass particles and its impact on dilute acid treatment. Bioresour. Technol., 83, 165-171, 0960-8524

Kim, TH., \& Lee, YY. (2005a). Pretreatment and fractionation of corn stover by ammonia recycle percolation process. Bioresour. Technol., 96,18, 2007-2013, 0960-8524

Kim, TH., \& Lee, YY. (2005b). Pretreatment of corn stover by soaking in aqueous ammonia. Appl. Biochem. Biotechnol., 121-124, 1119-1131, 0273-2289

Kim, TH, \&Lee, YY. (2006). Fractionation of corn stover by hot-water and aqueous ammonia treatment. Bioresour. Technol., 97, 2, 224-232 , 0960-8524

Kim, TH., \& Lee, YY. (2007). Pretreatment of corn stover by soaking in aqueous ammonia at moderate temperatures. Appl. Biochem. Biotechnol., 136-140, 81-92, 0273-2289

Kim, TH., Kim, JS., Sunwoo, C., \& Lee, YY. (2003). Pretreatment of corn stover by aqueous ammonia. Bioresour. Technol. 90,39-47, 0960-8524

Kim, TH., Lee, YY., Sunwoo, C., \& Kim JS. (2006). Pretreatment of corn stover by low liquid ammonia percolation process. Appl. Biochem. Biotechnol., 133, 41-57, 0273-2289

Kim, TH., Nghiem, NP., \& Hicks, KB. (2009). Pretreatment and fractionation of corn stover by soaking in ethanol and aqueous ammonia. Appl. Biochem. Biotechnol., 153, 13,171-179, 0273-2289

Lai, YZ. (2001). Chemical degradation. Chapter 10 In: Wood and cellulosic chemistry (David N.-S. Hon and Nobuo Shiraishi), Marcel Dekker Inc., New York- Basel, pp .443-512, 08247-00244

Lee, SH., Teramoto, Y., \& Endo, T. (2009). Enzymatic saccharification of woody biomass micro/nanofibrillated by continuous extrusion process I - Effect of additives with cellulose affinity. Bioresour. Technol., 100, 1, 275-279, 0960-8524

Linde, M., Galbe, M., \& Zacchi, G. (2006). Steam pretreatment of acid-sprayed and acidsoaked barley straw for production of ethanol. Appl. Biochem. Biotechnol., 130, 1-3, 546-562, 0273-2289

Linko, P., Mattson, C., Linko, YY., \& Antila, J. (1984). Production of fat bread by continuous extrusion cooking from high a-amylase. J Cereal Sci., 2, 43-51, 0733-5210

Little, AD. (2001). Aggressive growth in the use of bioderived energy and products in the United States by 2010. Final Report. www.adltechnology.com

Liu, C., \& Wyman, C. (2005). Partial flow of compressed-hot water through corn stover to enhance hemicellulose sugar recovery and enzymatic digestibility of cellulose. Bioresour. Technol., 96,1978-1985, 0960-8524

Liu, L., Sun, J., Li, M., Wang, S., Pei, H., \& Zhang, J. (2009). Enhanced enzymatic hydrolysis and structural features of corn stover by $\mathrm{FeCl}_{3}$ pretreatment. Bioresour. Technol., 100, 23, 5853-5858, 0960-8524

Liu, Q., Cheng, K., Zhang, J., Li, J., \& Wang, G. (2010). Statistical optimization of recycledpaper enzymatic hydrolysis for simultaneous saccharification and fermentation via central composite design. Appl. Biochem. Biotechnol. 160, 604-612, 0273-2289

Lloyd, TA., \& Wyman, CE. (2005). Combined sugar yields for dilute sulfuric acid pretreatment of corn stover followed by enzymatic hydrolysis of the remaining solids. Bioresour. Technol., 96, 1967-1977, 0960-8524 
Lu, XB., Zhang, YM., Yang, J., \& Liang, Y. (2007). Enzymatic hydrolysis of corn stover after pretreatment with dilute sulfuric acid. Chem. Eng. Technol. 30, 7, 938-944, 0930-7516

Lu, Y., \& Mosier, N. (2008). Kinetic modeling analysis of maleic acid catalyzed hemicellulose hydrolysis in corn stover. Biotechnol. Bioeng., 101, 6, 1170-1181, 1097-0290

Lu, Y., Wang, Y., Xu, G., Chu, J., Zhuang, Y., \& Zhang, S. (2010). Influence of high solid concentration on enzymatic hydrolysis and fermentation of steam-exploded corn stover biomass. Appl. Biochem. Biotechnol., 160, 360-369, 0273-2289

Lu, YL., \& Mosier, NS. (2007). Biomimetic catalysis for hemicellulose hydrolysis in corn stover. Biotechnol. Prog., 23, 1, 116-123, 1520-6033

Lynd, LR., van Zyl, WH., McBride, JE., \& Laser, M. (2005). Consolidated bioprocessing of cellulosic biomass: an update. Current Opin. Biotechnol., 16, 577-583, 0958-1669

MacDonald, DG., Bakhshi, NN., Mathews, JF., Roychowdhury, A., Bajpai, P., \& Moo-Young, M. (1983). Alkali treatment of corn stover to improve sugar production by enzymatic hydrolysis. Biotechnol. Bioeng., 25, 2067-2076

Mani, S., Tabil, LG., \& Sokhansanj, S. (2004). Grinding performance and physical properties of wheat and barley straw, corn stover, and switchgrass. Biomass Bioenerg. 27, 339352, 0961-9534

Martin, C., Klinke, HB., \& Thomsen, AB. (2007). Wet oxidation as a pretreatment method for enhancing the enzymatic convertibility of sugarcane bagasse. Enz. Micro. Technol., 40, 3, 426-432, 0141- 0229

Miller, S., \& Hester, R. (2007). Concentrated acid conversion of pine softwood to sugars Part I: Use of a twin-screw reactor for hydrolysis pretreatment. Chem. Eng. Comm., 194, 1, 185-102, 1563-5201

Mosier, N., Hendrickson, R., Ho, N., Sedlak, M., \& Ladisch, MR. (2005). Optimization of pH controlled liquid hot water pretreatment of corn stover. Bioresour. Technol., 96, 18,1986-1993, 0960-8524

Muthukumarappan, K., \& Julson, JL. (2007). Pretreatment of biomass using a novel extrusion process. 15th European Biomass Conference \& Exhibition from Research to Market Development, pp583-586. Florence, Italy: ETA srl 7-11 May 2007

National Research Council. (2000). Biobased industrial products- priorities of research and commercialization. National academy press, Washington, DC

Neureiter, M., Danner, H., Thomasser, C., Saidi, B., \& Braun, R. (2002).Dilute acid hydrolysis of sugarcane bagasse at varying conditions. Appl. Biochem. Biotechnol., 98-100, 49-58, 0273-2289

Öhgren, K., Rudolf, A., Galbe, M., \& Zacchi, G. (2006). Fuel ethanol production from steampretreated corn stover using SSF at higher dry matter content. Biomass Bioenerg., 30, 10, 863-869, 0961-9534

Öhgren, K., Bura, R., Saddler, J., \& Zacchi, G. (2007). Effect of hemicellulose and lignin removal on enzymatic hydrolysis of steam pretreated corn stover. Bioresour. Technol., 98, 13, 2503-2510, 0960-8524

Pedersen, M., \& Meyer, AS. (2009). Influence of substrate particle size and wet oxidation on physical surface structures and enzymatic hydrolysis of wheat straw. Biotechnol. Prog. 25, 2, 399-408, 1520-6033

Perlack ,RD., Wright, LL., Turhollow, AF., Graham, RL., Stokes, BJ., \& Erbach, DC. (2005). Biomass as feedstock for a bioenergy and bioproduct industry: The technical feasibility of a billion-ton annual supply, U.S. DOE and USDA, April 2005 
Rahman, SHA., Choudhury, JP., Ahmad, AL., \& Kamaruddin, AH. (2007). Optimization studies on acid hydrolysis of oil palm empty fruit bunch fiber for production of xylose. Bioresour. Technol., 98, 3, 554-559, 0960-8524

Rodgers, M., Hu, Z., \& Zhan, X. (2009). Enhancing enzymatic hydrolysis of maize stover by bayer process sand pretreatment. Energy \& Fuels, 23, 4, 2284-2289, 1520-5029

Rodríguez, A., Moral, A., Sánchez, R., Requejo, A., \& Jiménez, L. (2009). Influence of variables in the hydrothermal treatment of rice straw on the composition of the resulting fractions. Bioresour. Technol., 100, 20, 4863-4866, 0960-8524

Saha, B., \& Bothast, R. (1997). Enzymes in lignocellulosic biomass conversion. In: Fuels and Chemicals from Biomass. ACS Symposium Series, 666,46-56, 0097-6156

Sassner, P., Martensson, C-G., Galbe, M., \& Zacchi, G. (2008). Steam pretreatment of $\mathrm{H}_{2} \mathrm{SO}_{4}$ impregnated Salix for the production of bioethanol. Bioresour. Technol., 99, 1, 137$145,0960-8524$

Schell, DJ., Farmer, J., Newman, M., \& Mcmillan, JD. (2003). Dilute-sulfuric acid pretreatment of corn stover in pilot-scale reactor investigation of yields, kinetics, and enzymatic digestibilities of solids. Appl. Biochem. Biotechnol., 105-108, 69-85, 0273-2289

Selig, M., Weiss, N., Ji, Y. (2008). Enzymatic saccharification of lignocellulosic biomass. NREL/TP-510-42629. National Renewable Energy Laboratory, Golden, CO

Service, RF. (2007). Cellulosic ethanol: Biofuel researchers prepare to reap a new harvest. Sci. 315,1488-1491.

Sluiter, A., Hames, B., Ruiz, R., Scarlata, C., Sluiter, J., Templeton, D., \& Crocker, D.(2008a) Determination of structural carbohydrates and lignin in biomass. NREL/TP-51042618. National Renewable Energy Laboratory, Golden, CO

Sluiter, A., Hames, B., Ruiz, R., Scarlata, C., Sluiter, J., \& Templeton, D. (2008b). Determination of ash in biomass. NREL/TP-510-42622. National Renewable Energy Laboratory, Golden, $\mathrm{CO}$

Sluiter, A., Hames, B., Hyman, D., Payne, C., Ruiz, R., Scarlata, C., Sluiter, J., Templeton, D., \& Wolfe, J. (2008c).Determination of total solids in biomass and total dissolved solids in liquid process samples. NREL/TP-510-42621. National Renewable Energy Laboratory, Golden, CO

Sluiter, A., Hames, B., Ruiz, R., Scarlata, C., Sluiter, J., \& Templeton, D. (2008d). Determination of sugars, byproducts, and degradation products in liquid fraction process samples. NREL/TP-510-42623. National Renewable Energy Laboratory, Golden, $\mathrm{CO}$

Taherzadeh, MJ., Niklasson, C., \& Lidén G. (1997). Acetic acid - Friend or foe in anaerobic batch conversion of glucose to ethanol by Saccharomyces cerevisiae? Chem. Eng. Sci., $52,15,2653-2659,0009-2509$

Teramoto, Y., Lee, SH., \& Endo, T. (2009). Cost reduction and feedstock diversity for sulfuric acid-free ethanol cooking of lignocellulosic biomass as a pretreatment to enzymatic saccharification. Bioresour. Technol., 100, 20, 4783-4789,

Teymouri, F., Laureano-Perez, L., Alizadeh, H., \& Dale, BE. (2005). Optimization of the ammonia fiber explosion (AFEX) treatment parameters for enzymatic hydrolysis of corn stover. Bioresour. Technol. 96, 18, 2014-2018, 0960-8524 
Titgemeyer, EC., Cochran, RC., Towne, EG., Armendariz, CK., \& Olson, KC.(1996). Elucidation of factors associated with the maturity-related decline in degradability of big bluestem cell wall. J Animal Sci., 74, 3, 648-657, 0021-8812

Toma's-Pejo', E., Oliva, JM., Ballesteros, M., \& Olsson, L. (2008). Comparison of SHF and SSF processes from steam-exploded wheat straw for ethanol production by xylosefermenting and robust glucose-fermenting Saccharomyces cerevisiae strains. Biotechnol. Bioeng., 100, 6, 1122-1131, 1097-0290

Torget, R., Walter, P., Himmel, M., \& Grohmann, K. (1991). Dilute acid pretreatment of corn residues and short-rotation woody crops. Appl. Biochem. Biotechnol., 28/29, 75-86, 0273-2289

Tucker, MP., Kim, KH., Newman, MM., \& Nguyen, QA. (2003). Effects of temperature and moisture on dilute-acid steam explosion pretreatment of corn stover and cellulase enzyme digestibility. Appl. Biochem. Biotechnol. 105-108, 165-177, 0273-2289

Vainionpaa, J., \& Malkki, Y. (1987). Extrusion cooking in the manufacture of intermediate moisture food and feed. In 7th World Congress of Food Science and Technology, Ghee AH (ed.). Singapore Institute of Food Science and Technology: Singapore,1987, pp. 338- 345

van Walsum, G., Allen, SG., Spencer, MJ., Laser, MS., Antal, MJ., \& Lynd, LR. (1996). Conversion of lignocellulosics pretreated with hot compressed liquid water to ethanol. Appl. Biochem. Biotechnol., 57/58, 157-170, 0273-2289

Varga, E., Szengyel, Z., \& Reczey, K.(2002). Chemical pretreatments of corn stover for enhancing enzymatic digestibility. Appl. Biochem. Biotechnol., 98-100, 73-87, 02732289

Varga, E., Schmidt, AS., Reczey, K., \& Thomsen, AB. (2003). Pretreatment of corn stover using wet oxidation to enhance enzymatic digestibility. Appl. Biochem. Biotechnol., 104, 37-50, 0273-2289

Weiss, ND., Nagle, NJ., Tucker, MP., \& Elander, RT. (2009). High xylose yields from dilute acid pretreatment of corn stover under process-relevant conditions. Appl. Biochem. Biotechnol., 155, 1-3, 418-428, 0273-2289

Xin, L., \& Saka, S.(2008). Optimization of Japanese beech hydrolysis treated with batch hotcompressed water by response surface methodology. Inter. J Agric. Bio. Eng., 1, 2, 239-245, 1934-6352

$\mathrm{Xu}$, J., Thomsen, MH., \& Thomsen, AB. (2009a). Pretreatment on corn stover with low concentration of formic acid. J Microbiol. Biotechnol., 19, 8, 845-850, 1738-8872

$\mathrm{Xu}$, J., Thomsen, MH., \& Thomsen, AB. (2009b). Enzymatic hydrolysis and fermentability of corn stover pretreated by lactic acid and/or acetic acid. J Biotechnol., 139, 4, 300-305, 0168-1656

Yan, L., Zhang, H., Chen, J., Lin, Z., Jin, Q., Ji, H., \& Huang, H. (2009). Dilute sulfuric acid cycle spray flow-through pretreatment of corn stover for enhancement of sugar recovery. Bioresour. Technol., 100, 5, 1803-1808, 0960-8524

Yang, C., Shen, Z., Yu, G., \& Wang, J. (2008). Effect and aftereffect of $\gamma$ - radiation pretreatment on enzymatic hydrolysis of wheat straw. Bioresour. Technol., 99, 14, 6240-6245, 0960-8524

Yeh, A-I., \& Jaw, Y-M. (1998).Modeling residence time distributions for single screw extrusion process. J Food Eng., 35, 211-232, 0260-8774 
Yu, L., Ramaswamy, HS., \& Boye, J. (2009). Twin-screw extrusion of corn flour and soy protein isolate (spi) blends: A response surface analysis. Food Bioprocess Technol., DOI 10.1007/s11947-009-0294-8, 1935-5149

Yu, G., Yano, S., Inoue, H., Inoue, S., Endo, T., \& Sawayama, S. (2010). Pretreatment of rice straw by a hot-compressed water process for enzymatic hydrolysis. Appl. Biochem. Biotechnol., 160, 2, 539-551, 0273-2289

Zeng, M., Mosier, NS., Huang, C-P., Sherman, DM., \& Ladisch, MR. (2007). Microscopic examination of changes of plant cell structure in corn stover due to hot water pretreatment and enzymatic hydrolysis. Biotechnol. Bioeng., 97, 265-278, 1097-0290

Zhu, Y., Lee, YY., \& Elander, RT. (2004). Dilute-acid pretreatment of corn stover using a high-solids percolation reactor. Appl. Biochem. Biotechnol., 117, 103-114, 0273-2289

Zhu, Y., Lee, YY., \& Elander, RT. (2005). Optimization of dilute-acid pretreatment of corn stover using a high-solids percolation reactor. Appl. Biochem. Biotechnol., 124, 1-3, 1045-1054, 0273-2289

Zhu, Z., Sathitsuksanoh, N., Vinzant, T., Schell, DJ., McMillan, JD., \& Zhang, Y-HP. (2009). Comparative study of corn stover pretreated by dilute acid and cellulose solventbased lignocellulose fractionation: Enzymatic hydrolysis, supramolecular structure, and substrate accessibility. Biotechnol. Bioeng., 103, 4, 715-724, 1097-0290

Zimbardi, F., Viola, E., Nanna, F., Larocca, E., Cardinale, M., \& Barisano, D. (2007). Acid impregnation and steam explosion of corn stover in batch processes. Ind. Crops Prod., 26, 2,195-206, 0926-6690 


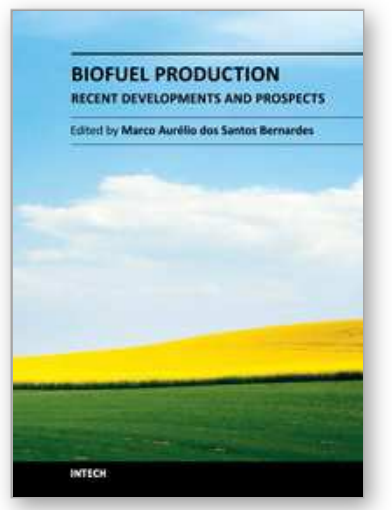

\section{Biofuel Production-Recent Developments and Prospects \\ Edited by Dr. Marco Aurelio Dos Santos Bernardes}

ISBN 978-953-307-478-8

Hard cover, 596 pages

Publisher InTech

Published online 15, September, 2011

Published in print edition September, 2011

This book aspires to be a comprehensive summary of current biofuels issues and thereby contribute to the understanding of this important topic. Readers will find themes including biofuels development efforts, their implications for the food industry, current and future biofuels crops, the successful Brazilian ethanol program, insights of the first, second, third and fourth biofuel generations, advanced biofuel production techniques, related waste treatment, emissions and environmental impacts, water consumption, produced allergens and toxins. Additionally, the biofuel policy discussion is expected to be continuing in the foreseeable future and the reading of the biofuels features dealt with in this book, are recommended for anyone interested in understanding this diverse and developing theme.

\section{How to reference}

In order to correctly reference this scholarly work, feel free to copy and paste the following:

Chinnadurai Karunanithy and Kasiviswanathan Muthukumarappan (2011). Application of Response Surface Methodology to Optimize Alkali Concentration, Corn Stover Particle Size, and Extruder Parameters for Maximum Sugar Recovery, Biofuel Production-Recent Developments and Prospects, Dr. Marco Aurelio Dos Santos Bernardes (Ed.), ISBN: 978-953-307-478-8, InTech, Available from:

http://www.intechopen.com/books/biofuel-production-recent-developments-and-prospects/application-ofresponse-surface-methodology-to-optimize-alkali-concentration-corn-stover-particle-si

\section{INTECH}

open science | open minds

\section{InTech Europe}

University Campus STeP Ri

Slavka Krautzeka 83/A

51000 Rijeka, Croatia

Phone: +385 (51) 770447

Fax: +385 (51) 686166

www.intechopen.com

\section{InTech China}

Unit 405, Office Block, Hotel Equatorial Shanghai

No.65, Yan An Road (West), Shanghai, 200040, China

中国上海市延安西路65号上海国际贵都大饭店办公楼 405 单元

Phone: +86-21-62489820

Fax: $+86-21-62489821$ 
(C) 2011 The Author(s). Licensee IntechOpen. This chapter is distributed under the terms of the Creative Commons Attribution-NonCommercialShareAlike-3.0 License, which permits use, distribution and reproduction for non-commercial purposes, provided the original is properly cited and derivative works building on this content are distributed under the same license. 